\title{
Leisure boredom and adolescent risk behaviour: a systematic literature review
}

\author{
Lisa Wegner 1,2* and Alan J Flisher ${ }^{2}$ \\ 1 Department of Occupational Therapy, University of the Western Cape, Private Bag X17, Bellville 7535, \\ South Africa \\ 2 Adolescent Health Research Unit, University of Cape Town and Red Cross War Memorial Children's \\ Hospital, Klipfontein Road, Rondebosch 7700, South Africa \\ * Corresponding author, e-mail: lwegner@uwc.ac.za
}

There has been very little research investigating leisure boredom and risk behaviour among adolescents in South Africa. A systematic review of literature was conducted to synthesise current knowledge within the field of leisure boredom and risk behaviour among adolescents. An online and a hand search for relevant articles were conducted using keywords. This resulted in the retrieval of 25 articles that met the inclusion criteria. It was evident that the experience of leisure boredom is influenced by a variety of different factors, not least of which is the environment or context within which adolescents are situated. A key finding was how few studies have focussed on leisure boredom and risk behaviour in adolescents, particularly in the developing world. Also, gaps in the knowledge basis were identified, thus providing direction for future research. The review focuses attention on leisure boredom as a factor contributing to risk behaviour in adolescents. Expanding knowledge in this area is useful for individuals and organisations concerned with adolescent health, education and development.

\section{Introduction}

The prevalence of risk behaviour among adolescents in South Africa has been welldocumented (for example, Flisher et al. 2006, Reddy et al. 2003, Shisana et al. 2005). Knowing the extent of the problem is important, but it seems equally necessary to understand the factors that are associated with, and predict, risk behaviour. One such factor is leisure boredom; however, nearly all of the studies investigating leisure boredom and risk behaviour have been conducted in the developed world. Consequently, in developing countries, very little is known about the experience of leisure boredom and how this is associated with risk behaviour in young people. Although many of the developmental tasks of adolescence are similar for adolescents all over the world, there are differences, not least of which arise due to the influences of different contexts, such as socio-economic environments and living conditions.

Many studies cite boredom - either generally, or during leisure or free time - as a factor in adolescent risk behaviour. Despite this, there are remarkably few studies that have focused specifically on leisure boredom as a construct and its association with risk behaviour among adolescents. To the best of our knowledge, prior to 1987 no research anywhere in the world had investigated the relationship between leisure and boredom. It appears that Iso-Ahola and Weissinger (1987) were the first scientists to conduct research in this field by examining factors that contributed to a sense of leisure boredom among adults $(\mathrm{n}=134)$. The authors found that a lack of awareness of the psychological value of leisure, having a negative attitude towards leisure, being less self-motivated, and constraints to leisure contributed significantly to the perception of boredom in leisure. With the development of the Leisure Boredom Scale (LBS) (Iso-Ahola and Weissinger 1987) that measures individual differences in perceptions of 
boredom in leisure', research investigating leisure boredom and the association with risk behaviour started to emerge.

Only one review of literature about leisure boredom and alcohol and drug abuse among young people could be located; however, this review focused specifically on young people living in rural Australia. The review provided evidence that youth (especially young males) in this area experi- enced high levels of leisure boredom and tended to drink large quantities of alcohol, which resulted in feelings of alienation and marginalisation that put them at greater risk of depression and suicide (Patterson and Pegg 1999).

\section{Research questions and aim}

As no previous systematic and comprehensive review of the literature on leisure boredom and risk behaviour among adolescents was available, the study addressed the following research questions:

(1) What evidence is there of leisure boredom among adolescents, and its association with risk behaviour?

(2) How has leisure boredom been measured?

(3) What interventions have addressed leisure boredom among adolescents?

The aim of the study was to summarise, synthesise and critically evaluate empirical research on this topic by describing findings from cross-sectional and longitudinal studies of leisure boredom among adolescents, and identify areas that warranted further research.

\section{Methods}

A database search for relevant articles was conducted on Medline, Psychinfo, the Cochrane library, African Health Anthology, PubMed, Healthstar, Ovid, PsychLit, Sociofile, Social Sciences Index, Index to South African Periodicals, SportDiscus, Academic Search Premier, ERIC, Health Source, PsycARTICLES, SocINDEX and BiblioLine (Africa-wide which includes South African and African studies). An online search was conducted and details of published work were obtained using combinations of the following keywords: leisure, free time, boredom, leisure boredom, free time boredom, adolescence, adolescents, teenagers, youth, risk behaviour, race, gender, age, school grade, substance use/abuse/dependence, alcohol use/abuse/dependence, sexual behaviour, violent behaviour, and school dropout. The reference lists of retrieved articles were scanned to identify further relevant publications. A hand search was done by scanning tables of contents for relevant journals. Where possible, prominent scholars and researchers were contacted to request articles and ensure that all relevant publications had been accessed.

Studies were included in the review based on the criteria listed below. No time frame applied and all studies that could be located (regardless of when they were published), were included. Studies were included if they:

- Addressed the investigation of, or the measurement of, or intervention for leisure or free time boredom, and risk behaviour.

- Had population samples that included primarily adolescents and young adults.

- Were English-language articles.

- Were published in peer-reviewed journals or books.

- Made use of quantitative methods of enquiry.

An effort to reduce potential researcher bias involved consultation between the researchers and an expert in the field of leisure research (Dr Linda Caldwell, see references) to ensure that all relevant and available studies were included. Studies that met the inclusion criteria were analysed through a process of extracting relevant data and summarising these in tables under the headings: authors, journal, title, risk behaviours, sample, age, gender, ethnicity, school grade, 
rural/urban, location, design, sampling strategy, methods of data collection, measures, validity and reliability, analysis, theoretical framework and/ or hypothesis, findings, and limitations.

\section{Results and discussion}

\section{Sample}

\section{Study locations}

The search resulted in the retrieval of 25 articles that met the inclusion criteria. A description of the study samples, measurements and variables is given in Appendix 1. The majority of the studies were conducted in the developed world, with 16 studies from the USA (Barnett 2005, Barnett and Klitzing 2006, Caldwell et al. 2004, Caldwell et al. 1999, Caldwell and Kivel 1998, Caldwell and Smith 1994, Caldwell and Smith 1995, Iso-Ahola and Crowley 1991, Iso-Ahola and Weissinger 1990, Larson and Richards 1991, Newberry and Duncan 2001, Sharp et al. 2006, Weissinger, Caldwell and Bandolas 1992, Widmer, Ellis and Munson 2003, Widmer, Ellis and Trunnell 1996, Yang and Yoh 2005). Two studies were from Canada (Caldwell, Smith and Weissinger 1992, Shaw, Caldwell and Kleiber 1996) and three studies were from Australia (Farnworth 1998, Gordon and Caltabiano 1996, Patterson, Pegg and Dobson-Patterson 2000). Only four studies were conducted in the developing world, all of them in South Africa (Caldwell et al. 2004, Kaufman et al. 2002, Møller 1991, Wegner et al. 2006).

Of the South African studies, only one (Wegner et al. 2006) specifically investigated leisure boredom and risk behaviour (substance use). The second study (Møller 1991); investigated the leisure prospects of black urban township youth between 1988 and 1991; however, the study took place during the latter years of the apartheid system and the results should be considered within this context. The third South African study was a description of a pilot study for an intervention that addressed leisure boredom (and other risk behaviour) by means of a comprehensive school-based life skills curriculum called HealthWise (Caldwell et al. 2004). The fourth study was included because it considered how adolescents' use of time influenced sexual risk behaviour (Kaufman et al. 2002).

Whether studies were conducted in an urban versus a rural context was not considered as a factor for comparison of studies (although this is indicated in Appendix 1), as the definition of these constructs varies widely depending on the location of the study. For example, in South Africa rural areas are typically remote parts of the country where people often live in very traditional ways and where there are few amenities such as electricity, running water and shops. In the USA, rural areas usually refer to towns with relatively small populations that often have an agricultural focus.

\section{Study sampling procedures}

Eleven of the studies made use of random sampling (Caldwell et al. 2004, Caldwell and Kivel 1998, Caldwell et al. 2004, Caldwell and Smith 1995, Caldwell et al. 1992, Kaufman et al. 2002, Larson and Richards 1991, Møller 1991, Sharp et al. 2004, Wegner et al. 2006, Widmer et al. 2003). Six studies included students who were enrolled in specific classes (Gordon and Caltabiano 1996, Iso-Ahola and Weissinger 1990; Patterson et al. 2000, Shaw et al. 1996, Weissinger et al. 1992, Widmer et al. 1996); thus providing samples that were not strictly random in nature. Four studies made use of voluntary sampling (Barnett 2005, Barnett and Klitzing 2006, Caldwell et al. 1999, Newberry and Duncan 2001), which may have introduced a degree of bias into the studies. Four studies used non-probability sampling based on the availability of respondents (Caldwell and Smith 1994, Farnworth 1998, Iso-Ahola and Crowley 1991, Yang and Yoh 2005). Thus, there exists a degree of heterogeneity within the sampling procedures of the studies, which might account for any variations in findings across studies and make direct comparisons of findings difficult. 
Twelve study samples involved school students (Caldwell et al. 2004, Caldwell et al. 1999, Caldwell and Kivel 1998, Caldwell et al. 2004, Caldwell and Smith 1995, Caldwell et al. 1992, Gordon and Caltabiano 1996, Larson and Richards 1991, Newberry and Duncan 2001, Sharp et al. 2004, Shaw et al. 1996, Wegner et al. 2006). Six study samples involved college or university students (Barnett 2005, Barnett and Klitzing 2006, Patterson et al. 2000, Iso-Ahola and Weissinger 1990, Weissinger et al. 1992, Yang and Yoh 2005). Five studies included special groups of youth such as those identi- fied as high-risk (Caldwell and Smith 1994) and criminal offenders on probation (Farnworth 1998), and those attending substance use centres (Iso-Ahola and Crowley 1991), detention centres (Widmer et al 1996) and psychiatric treatment centres (Widmer et al. 2003). Two studies involved a mix of youths who were at school, or working or unemployed (Kaufman et al. 2002, Møller 1991).

The majority of the studies involved mainstream school-going or college students indicating a degree of homogeneity in these 18 samples. Only one study involved disabled youth (Yang and Yoh 2005), and no study focused specifically on adolescent dropouts; thus reflecting extremely limited research among these marginalised groups and indicating scope for future research.

\section{Study designs}

The majority of the studies were cross-sectional in design $(n=22)$, with only three of the studies being longitudinal (Caldwell et al. 2004, Caldwell et al. 1999, Sharp et al. 2006). The relatively low number of longitudinal studies reflects the lack of maturity in the field. Also, longitudinal studies are more costly and time consuming than cross-sectional studies; however, they provide a far more comprehensive investigation of a situation over time and allow for causal predictions to be made about variables.

The majority of studies ( $\mathrm{n}=22$ ) involved the use of self-report questionnaires or surveys. The advantage of self-report questionnaires is that large numbers of respondents can be surveyed more economically and in a shorter time, the anonymity and privacy encourage more candid responses, and reliability can be established (Babbie and Mouton 2001). However, they do require respondents to be literate (which may be problematic especially when surveying young adolescents where literacy is a definite problem - as in many parts of South Africa). Thus, face-to-face interviews mean fewer incomplete questionnaires and misunderstood questions. Five studies examined use of time by means of interviews, and either experience sampling methods (Farnworth 1998, Larson and Richards 1991), or time-use diaries (Caldwell et al. 1999, Kaufman et al. 2002, Møller 1991, Shaw et al. 1996). Experience sampling methods (Csikszentmihalyi and Larson 1987) entail the use of electronic pagers which bleep respondents who then need to complete a report. This method can be costly and requires a certain level of commitment from the respondent, although the method seems to have been used successfully in the studies.

\section{Evidence of leisure boredom}

The findings of the studies were examined for evidence of the experience of leisure boredom, which was then categorised into three broad themes according to the causes of boredom: (1) social control, (2) psychological disposition, and (3) the influence of context. Of interest, although not surprising, was that the first two themes are theories relating to boredom, but these were equally well suited to explain leisure boredom. A summary of findings about evidence of leisure boredom, and the association with risk behaviours is presented in Appendix 2.

Social control and leisure boredom

Social control theory refers to the social mechanisms that regulate the choices individuals make about engaging in activities and behaviour, which lead to conformity and compliance with the 
rules of society (Hirschi 1969). Thus, parents, teachers, schools and societal laws constitute examples of social mechanisms that may directly or indirectly exert control over adolescents in an effort to avoid deviant or negative behaviour. Hirschi (1969) suggested that involvement in activities such as structured recreation strengthens social bonds by promoting attachment, commitment, involvement and belief in a common value, and reduces delinquent behaviour. However, as adolescents are striving for autonomy, any mechanism that constrains this drive may be met with resistance, which can be expressed as boredom. Shaw, et al. (1996) found support for the notion that social control mechanisms lead to a lack of choice in free time activities and feelings of boredom in adolescents, in response to adult restrictions, structures and expectations. As discussed in the next section, parental monitoring, gender and developmental age are factors that can be linked with social control mechanisms, and thus influence the experience of leisure boredom.

\section{Parental monitoring}

Parents influence their children's experience of leisure boredom through the extent to which they monitor their children's activities. Not unsurprisingly, younger adolescents and girls were monitored by parents to a greater extent (Møller 1991, Sharp et al. 2006). Adolescents who perceived lower levels of parental monitoring were more likely to be bored (Caldwell et al. 1999); however, these were 13-year olds, and this developmental age group would expect their parents to have greater knowledge of their whereabouts and activities. Sharp et al. (2006) referred to this as parental knowledge and found that it had a positive effect on adolescent interest, motivation and self-regulation in free time. On the other hand, parental control occurs when parental monitoring is regarded as restricting autonomy in leisure. This had a negative effect on interest, and was associated with amotivation (Sharp et al. 2006).

\section{Gender and identity}

The literature is divided as to the likelihood of experiencing boredom as a function of gender. The lives of adolescent girls appear to be subject to more restrictions as a result of social control mechanisms than boys, and girls spend more time in obligatory activities than boys (Shaw et al. 1996). Accordingly, it may be expected that girls might experience greater leisure boredom than boys. Several studies found evidence supporting this notion. Females in South Africa (Wegner et al. 2006) and in rural areas of Australia (Patterson et al. 2000) experienced higher levels of boredom than boys. Gender significantly moderated relationships between individual characteristics and boredom in free time (Barnett and Klitzing 2006). Other studies found that males reported higher boredom (Shaw et al. 1996) and were more prone to boredom (Newberry and Duncan 2001) than females.

Gay youth, and youth questioning their sexual identity, experienced leisure differently and more negatively than their non-gay peers (Caldwell and Kivel 1998). Gay males were more bored in their leisure time, tended to use free time to rebel, and reported that their parents had too much control over their free time. They were less likely to do healthy pursuits in their free time, go out for fun in the evening, and engage in aerobic activity. They were also more likely to engage in binge drinking, feel sad, depressed, under pressure and stressed, and attempt suicide (Caldwell and Kivel 1998).

Other studies have found that gender was not a significant predictor of boredom (Caldwell et al. 1999; Weissinger et al. 1992). However, that studies differ with regard to gender findings may be attributed to the heterogeneity within the methodologies employed in the various studies, as mentioned previously. Caldwell et al. (1999) conducted their study with a small sample $(\mathrm{n}=82)$ of high-school students who volunteered to participate in the in-depth interviews and activity diary portion of the project; which may have introduced bias into the study. Weissinger et al. (1992) used convenience sampling to recruit their sample $(n=525)$ 
whose age range was 18-40 years (mean 20.9 years). The fact that this study also involved adults may have resulted in the finding that gender did not significantly predict boredom in this study.

Age

Age plays a role in the experience of leisure boredom. Boredom was higher among younger adolescents than older adolescents during school (Larson and Richards 1991) and leisure time (Wegner et al. 2006). It is likely that social control mechanisms are responsible for this finding; younger adoles- cents might be restricted from leisure engagement due to parental control, and other constraints such as lack of transport and money. However, there is not enough evidence to support this, and future research could examine this further.

\section{Psy chological disposition and leisure boredom}

\section{Motivation}

Self-determination theory (Deci and Ryan 1985) posits that the individual's need for intrinsic rewards - self-determination and competence - lies at the core of intrinsic motivation. The individual becomes aware of the need and that it can potentially be satisfied, and selects and enacts goal- oriented behaviour to meet the need. Individual differences in the desire for intrinsic rewards mediate this process. Weissinger et al. (1992) suggested that boredom was the result of a disruption in this process. The authors found that higher levels of desire for intrinsic rewards were negatively associated with leisure boredom. Intrinsic motivation to seek enjoyment was negatively related to leisure boredom (Barnett and Klitzing 2006). Adolescents with lower intrinsic motivation were more likely to be bored (Caldwell et al. 1999). A motivation was negatively related to adolescents' experiences of interest and positively associated with parental control (Sharp et al. 2006). Adolescents who were more motivated and self-regulated had parents who were more knowledgeable about their free time (Sharp et al. 2006). Thus, individual motivation is clearly a factor influencing leisure boredom.

\section{Personality and affect}

The literature provided support for the idea that individual disposition effects the experience of leisure boredom. The Aristotelian Ethical Behaviour in Leisure (AEBL) scale, and the shortened version - the AEBL-S - were used to measure intellectual and creative activity, meaningful relation- ships and moral behaviour among youth in the USA ( $\mathrm{n}=346, \mathrm{n}=2948$ respectively), and were shown to have a Cronbach's alpha score of 0.90 (Widmer et al. 1996; Widmer et al. 2003). The authors found that students who scored low on these scales also experienced higher levels of leisure boredom. Individuals who had difficulty entertaining themselves, who preferred fantasy and imagination, who were introverts, and who preferred novelty and variety in their free time were most likely to be bored (Barnett and Klitzing 2006). Those who had a generally negative affect (Barnett and Klitzing 2006) or who were depressed and had low self-esteem (Larson and Richards 1991) tended to be more bored.

\section{The influence of context on leisure boredom}

Having nothing to do

Context influences how adolescents choose to engage in activities and spend their free time. Situational differences (or the reasons for engaging in activities) accounted for $77 \%$ of variance in adolescents' reported boredom (Caldwell et al. 1999). When adolescents 'wanted to' take part in a leisure activity, the experience of leisure boredom was lower and intrinsic motivation was higher, compared to adolescents who were participating because they had to' or had nothing else to do' (Caldwell et al. 1999). Adolescents experienced boredom during school because they disliked certain classes, and thus felt forced to take part; however, outside of school, the most frequent explanation for boredom was that there was nothing to do (Larson and Richards 1991). 
Clearly, the evidence showed this to be the most common reason for leisure boredom, as $41 \%$ of the time adolescents felt there was nothing to do (Caldwell et al. 1999) and felt bored $42 \%$ of the time (Farnworth 1998).

\section{Limited leisure resources}

Contexts where there is a lack of awareness of the benefits of leisure, and environments that offer limited leisure resources contribute to the perception of having nothing to do, and thus, result in higher levels of leisure boredom. Students who reported being aware of leisure resources were significantly less bored in their free time than those who were less aware, and individuals who liked to experience a challenge in their leisure were usually less bored with their free time (Barnett 2005). Leisure boredom was found to be higher among black and coloured adolescents in Cape Town, South Africa (Wegner et al. 2006). The authors suggested that this may have been due to the poor living conditions and lack of leisure resources for the majority of these adolescents, but this is an area that requires further research. Youth who were not attending school and unemployed had more free time available yet were unable to fill this time, and more than half complained of feeling bored (Møller 1991). Evidence shows that adolescents, especially girls, living in rural parts of Australia experienced relatively higher leisure boredom than their urban counterparts (Patterson et al. 2000). Participation rates in passive leisure activities were highest for rural adolescents, and highest for social leisure in urban adolescents, resulting in rural adolescents experiencing higher levels of leisure boredom than urban adolescents (Gordon and Caltabiano 1996).

\section{Lack of challenge}

In line with the theory of boredom as lack of challenge (Csikszentmihalyi and Csikszentmihalyi 1988) and under arousal (Zuckerman 1990, 1991), when activities are perceived to be under challenging and provide insufficient stimulation, adolescents feel bored. Generally, engaging in passive leisure activities such as watching television and hanging out occurs as a result of having nothing else to do, and the outcome is a feeling of boredom. This is a common experience for adolescents, and juvenile offenders reported that $62 \%$ of their time was spent in under challenging activities in relation to their perceived skills, and that they experienced boredom with passive leisure activities more than active activities (Farnworth 1998).

\section{Time use}

Comparing the amount of time spent in leisure activities was difficult due to the different ways in which time use was measured. As a guide, we estimated adolescents to be asleep for approximately eight hours a day, leaving 16 hours for obligatory activities (such as schoolwork and chores) and non-obligatory activities (free time and leisure). In Australia, adolescents on average spent 54.7 hours per week on leisure (Gordon and Caltabiano 1996), which is approximately eight hours a day. For young offenders in Australia, 57\% (or about nine hours) of their waking time was spent in leisure occupations - predominantly passive leisure such as listening to music or watching TV (Farnworth 1998). Canadian adolescents spent half their waking time in non-obligatory activities (about eight hours a day), the most common nonobligatory activity being social activities with friends including hanging out, talking on the phone and going to parties (Shaw et al. 1996). Thus, it appears that Australian and Canadian adolescents have an average of eight to nine hours of free time daily.

Obtaining an aocurate picture of South African adolescents' use of time is difficult, as few studies have investigated this construct. Møller (1991) found that young black people on average have five hours free on weekdays, and seven-and-a-half hours free on weekend days, with dominant free time activities including conversations with friends, watching TV, listening to music, relaxing (which included doing nothing and thinking), reading, playing sports and other physical activities. A more recent time-use study showed that boys spend one to three hours a day time hanging out 
(defined as doing nothing, spending time at the mall or on street corners, going to bars or parties generally unsupervised and unstructured activities), compared to girls who spend one hour or less hanging out (Kaufman et al. 2002). However, both of these studies have limitations - Møller's study (1991) was conducted nearly two decades ago with black youth during the apartheid era, and Kaufman et al. (2002) conducted their study in and around Durban, South Africa. Thus, the findings of these two studies cannot be considered applicable or representative to other groups of adolescents in South Africa.

\section{Leisure boredom and risk behaviour}

The next phase of the literature review was to examine the studies for evidence of an association between leisure boredom and risk behaviour. The findings are presented in Appendix 2 .

\section{Substance use}

Studies in the developed world provided evidence that adolescent substance abusers were significantly more bored during their leisure time than non-substance users (Caldwell and Smith 1994, Iso-Ahola and Crowley 1991). Significant negative correlations were found between scores on the AEBL and the AEBL-S, and leisure boredom and substance use (Widmer et al. 1996, Widmer et al. 2003). In other words, students with less intellectual and creative activity, who lacked meaningful relationships and had lower moral standards and behaviour, experienced higher leisure boredom and used substances more than those who scored high on these variables. It is important to note that all of these studies included high-risk youth in special programmes.

In contrast to this, no significant association between leisure boredom and substance use was found among adolescents in Cape Town, South Africa (Wegner et al. 2006). However, this study did not include high-risk adolescents (in special programmes) and was conducted among students attending mainstream, public high schools. Finally, this was the only study in the developing world to have examined leisure boredom and risk behaviour. Clearly, more research needs to be done in the developing world to investigate this topic further.

\section{Sexual risk}

No studies examined sexual risk behaviour and leisure boredom specifically. However, a study of time use conducted in KwaZulu-Natal, South Africa, found that the number of hours spent hanging out was positively associated with having had sex in the last year (significant in African boys $\mathrm{p}=$ 0.000 , African girls $=0.000$ and Indian boys $p=0.031$ ) (Kaufman et al. 2002). Furthermore, the number of hours spent hanging out was negatively associated with condom use, although this was not significant for any group.

\section{Dropout}

No studies that examined dropout and leisure boredom were located.

\section{Negative affect and delinquency}

The review provided evidence for a link between leisure boredom, negative affect, delinquency and risk behaviour. Leisure-alienated youth - or those who felt bored in leisure time and used leisure to reject adult structure - engaged in higher risk behaviour (cigarette and alcohol use, vomiting on purpose, attempting suicide and being depressed) than their peers (Caldwell and Smith 1995). Boredom co-occurred with tiredness and drowsiness (under-stimulation), indicating a state of lower arousal, with frustration (forced-effort), and anger (resistance) (Larson and Richards 1991). This study also found that free-time boredom was significantly correlated with socially disruptive behaviour. Adolescents involved in delinquent activities were prone to experience boredom, and the tendency to experience boredom was significantly related 
to the number of arrestable behaviours reported (Newberry and Duncan 2001). Finally, among disabled college students, there was a positive correlation between aggressive behavioural tendency and free-time boredom, especially when respondents felt that time was standing still (Yang and Yoh 2005).

\section{Sensation seeking}

Some studies have investigated the relationship between leisure boredom, risk behaviour and sensation seeking. Significant two-way interaction effects between sensation-seeking, leisure boredom and self- esteem were found for substance use in both rural and urban adolescents in Australia (Gordon and Caltabiano 1996). In this study, urban adolescents who engaged most heavily in substance use had low self-esteem and high leisure boredom. Urban adolescents who scored high on both sensation-seeking and leisure boredom engaged most heavily in substance use. Substance-abusing adolescents reported higher leisure boredom and participated in leisure significantly more often than non-substance users (Iso-Ahola and Crowley 1991). The authors offered the explanation that substance-users tended to differ from non-substance users in that they were more likely to be sensation seekers with a low tolerance for repetitious activities (Zuckerman 1979) and became bored more easily, particularly if activities did not meet their need for optimal arousal and challenge (Csikszentmihalyi and Csikszentmihalyi 1988). This was supported by Caldwell and Smith (1994), who found that students who went out for fun five or more times a week were more bored and consumed higher levels of alcohol than their peers who went out less than five times a week. However, contrary to the findings of the above studies, Caldwell and Smith (1995) found that females who were bored engaged less in leisure activities than their peers, and bored males were less likely to go out in the evenings for fun.

An examination of the samples in these studies reveals certain differences that may explain the differences in the findings. Gordon and Caltabiano (1996) conducted their study with high-school students ( $\mathrm{n}=145$, mean age 14.3 years) in rural and urban Australia. The other three studies were all done in urban parts of the USA. Caldwell and Smith (1994) conducted their study with highrisk adolescents in a specialised programme $(\mathrm{n}=129$, age range 12- 16 years), and Iso-Ahola and Crowley (1991) conducted their study with adolescents diagnosed with substance use who were admitted to a treatment centre $(n=39$, mean age 16.6 years) and a control group of non-substance users from a private high school $(\mathrm{n}=81$, mean age 16.1 years). All of these studies had relatively small sample sizes, thus potentially lacking the necessary statistical power, in comparison to the study by Caldwell and Smith (1995) who conducted their study with 2756 high-school students in grades 9-12.There is clearly a need for further research on the role of sensation seeking in leisure boredom and risk behaviour.

\section{Measurement of leisure boredom}

Only three studies could be located that measured leisure boredom specifically. These are presented in Appendix 3. The Leisure Boredom Scale (LBS) (Iso-Ahola and Weissinger 1987, 1990) focused specifically on leisure boredom, while the Leisure Experience Battery (Caldwell et al. 1992, Barnett 2005) incorporated leisure boredom as one of four dimensions in the leisure experience.

Iso-Ahola and Weissinger (1987) devised the LBS based on literature regarding leisure and boredom constructs. The 16-item instrument is scored on a 1-5 scale, with higher scores indicating higher leisure boredom. Secondary analysis of three studies of American college students ( $\mathrm{n}=175, \mathrm{n}=174, \mathrm{n}=344$, mean age 21 years) provided support for the reliability and validity of the LBS, with Cronbach's alpha coefficients of $0.85,0.88$ and 0.86 for the respective studies. No test-retest reliability was carried out in any of these studies. In further support of the validity and usability of the LBS, all constructs significantly correlated in the predicted manner; leisure boredom was negatively related to social competence, self-esteem, self-as-entertainment, social desirability, intrinsic leisure motivation, social desirability, leisure satisfaction, leisure 
ethic, frequency of participation in leisure activities, and perceived satisfaction with mental and physical health (Iso-Ahola and Weissinger 1987). The authors suggested that further research was necessary to determine the applicability of the LBS with non-college student populations.

Caldwell et al. (1992) developed the Leisure Experience Battery for Adolescents (LEBA). This instrument includes four dimensions of leisure: (1) boredom (adapted from Iso-Ahola and Weissinger 1987); (2) awareness (adapted from Iso-Ahola and Weissinger 1987, Weissinger, Caldwell and Mobily 1987); (3) challenge (adapted from Weissinger 1985); and (4) anxiety (developed for the study based on literature). The study was conducted with grade 10 students ( $\mathrm{n}=1407$, mean age not given) in Ontario, Canada. Test-retest reliability was calculated by following up with these students in grade 11. Results from the internal consistency reliability analyses and the factor analysis indicated that the LEBA had promising reliability for use with adolescents, with Cronbach's alpha scores of 0.70 for boredom, 0.70 for challenge, 0.55 for awareness and 0.63 for anxiety. The authors felt that although these internal consistency scores were somewhat low, this was due to the low number of items in each scale rather than systematic error. The measures appeared to be consistent and stable over time, thus indicating that the LEBA could be used to evaluate the efficacy of leisure interventions where changes in scores could be interpreted as being due to the interven- tion rather than as a result of systematic error variance (Caldwell et al. 1992).

Barnett (2005) conducted a study to establish the psychometric properties of the LEBA with American college students ( $\mathrm{n}=657$, mean age 21 years). Results provided further support for the validity of the LEBA, with Cronbach's alpha scores of 0.73 for boredom, 0.72 for challenge, 0.67 for awareness, and 0.67 for anxiety (alpha increased to 0.74 when one item was deleted). Furthermore, the study provided support for the inclusion of boredom, challenge, awareness and anxiety as aspects of research about leisure among young people; however, there could be other factors that could also form part of a battery to measure leisure experiences.

It is important to note that all of these studies were conducted in North America. In order to use the LBS and the LEBA with different populations, the psychometric properties of these measurements would first need to be established. This is particularly so in the developing world, where social, cultural and economic differences may be more evident.

\section{Interventions for leisure boredom}

Only two studies reported on interventions that addressed leisure boredom. These are presented in Appendix 4. Both interventions were school-based interventions that aimed to reduce risk behaviour through positive use of free time. Time Wise (Caldwell et al. 2004) was implemented with mainly white grade 7 students in rural Pennsylvania, USA. Health Wise (Caldwell et al. 2004) was implemented with coloured and black grade 8 students in a low socio-economic area of Cape Town, South Africa. Time Wise was a longitudinal study that followed one cohort of grade 7 students through three years of schooling. The seven-lesson Time Wise curriculum focused specifically on leisure awareness and motivation, and developing leisure interests in an effort to reduce substance-use risk behaviour. The Health Wise curriculum was designed as a 17-lesson curriculum that incorporated components of the Time Wise intervention, but also included life skills such as anger management and conflict resolution in an effort to address both substance use and sexual risk behaviour. Students who participated in the Time Wise curriculum showed improvements in motivation, an increase in participation in new leisure activities, and a reduction in boredom (Caldwell et al. 2004). The Health Wise study was a description of the pilot study in preparation for a large randomised control trial; outcomes were therefore not available. However, the authors reported a positive response to the curriculum from participating educators and students. Once the outcomes are 
available it will be interesting to compare these two studies that had fairly similar goals and curricula, yet were conducted with totally different populations of students and settings.

\section{Limitations}

Certain limitations in this systematic review of the literature require consideration. Firstly, it is possible that there was a selection bias as only one researcher (as opposed to a team) conducted the search and decided which studies to include, although an effort was made to restrict this bias (see Methods). Secondly, the review did not include a meta-analysis as the studies did not all lend themselves to statistical comparison. Finally, only studies published in English were included. The implication of not including studies published in other languages is that important and relevant insights and knowledge may have been missed in this review. Spanish or Portuguese studies conducted in South America (as part of the developing world) may have provided useful comparisons for the present research.

\section{Further research}

A useful outcome of a systematic review of literature is that gaps in the knowledge base are revealed; thus, areas for further research can be identified. The most striking finding of this review was that from the perspective of the developing world, there has been very little research in the field of leisure boredom and risk behaviour among young people. In fact, the phenomenon of leisure boredom has received relatively little attention throughout the world.

There have been no investigations into the psychometric properties of measurements of leisure boredom among adolescent populations in the developing world. It is important that the reliability and validity of measurements is established before research about leisure boredom can be done in these contexts. No studies anywhere have investigated the association between leisure boredom, dropout from school and sexual risk. In South Africa, where problems such as dropout, substance use and sexual risk behaviour (leading to teenage pregnancy and sexually-transmitted infections including HIV) are concerning, it is vital that research be conducted to investigate the factors that are associated with these risk behaviours. Furthermore, most studies in this field are cross-sectional studies and very few longitudinal studies of leisure boredom exist. There is a need for more longitudinal studies of leisure boredom and risk behaviour, as these would reveal whether leisure boredom is a predictor of risk behaviour, and how this changes over time.

Despite leisure boredom being identified as a factor associated with risk behaviour in the developed world, there is a paucity of research that has determined the efficacy of interventions that address leisure boredom among young people. There is a need for such interventions to be developed, implemented, adapted and evaluated for their efficacy and effectiveness, in both the developed and the developing world. Cross-cultural comparisons of interventions and young people's responses to the interventions would further enhance this process of investigation. Building on this concept, another potential area of research is to conduct cross-cultural comparisons between different groups of adolescents regarding leisure boredom, related factors such as motivation and self-determination, and risk behaviour. This would give insight as to how the leisure experience differs or is similar in different contexts and environments.

Finally, only studies that employed quantitative methods of enquiry were included in this systematic review of the literature. However, the value and usefulness of using qualitative research to understand the phenomenon of leisure boredom and risk behaviour should not be underestimated. 


\section{Conclusion}

This systematic review has summarised and synthesised empirical research about leisure boredom among adolescents. Specifically, the review examined the evidence of leisure boredom in adolescents and the association with risk behaviour, measurement of leisure boredom, and interventions that have addressed leisure boredom among adolescents. Due to a degree of heterogeneity in the methodologies employed in the various studies, comparisons of findings were complicated. Gaps in the knowledge basis were identified, thus providing some direction for future research.

This review revealed that leisure boredom is a multi-faceted, complex phenomenon that warrants more attention from both researchers and programme developers. The most striking observation from this review was how few studies have actually focused on leisure boredom and risk behaviour in adolescents, despite the multitude of studies that have cited boredom in relation to risk behaviour. Furthermore, the experience of leisure boredom is influenced by a variety of different factors, not least of which is the environment or context within which adolescents are situated. It follows that leisure boredom is a phenomenon that requires further ongoing investigation in relation to adoles- cent risk behaviour. This is particularly vital in the developing world, where previous research in this regard has been seriously lacking. 


\section{References}

Amabile TM, Hill KG, Hennessey BA and Tighe EM (1994) The Work Preference Inventory: assessing intrinsic and extrinsic motivation orientations. Journal of Personality and Social Psychology 66: 950-967

Babbie E and Mouton J (2001) The Practice of Social Research. Cape Town: Oxford University Press

Baldwin CK and Caldwell LL (2003) Free time motivation scale for adolescents. Journal of Leisure Research 35: 129- 151

Barnett LA (2005) Measuring the ABCs of leisure experience: Awareness, boredom, challenge, distress. Leisure Sciences 27: 131- 155

Barnett LA and Klitzing SW (2006) Boredom in free time: relationships with personality, affect and motivation for different gender, racial and ethnic student groups. Leisure Sciences 28: 223- 244

Bronfenbrenner U (1992) Ecological systems theory. In: Vasta R (ed.), Six Theories of Child Development: Revised Formulations and Current Ideas. London: Jessica Kingsley Publishers. pp 187- 249

Bronfenbrenner U (1995) Developmental ecology through space and time: A future perspective. In: Moen P, Elder GH Jr and Luscher K (eds.), Examining Lives in Context. Washington: American Psychological Association

Caldwell LL, Baldwin CK, Walls T and Smith EA (2004) Preliminary effects of a leisure education program to promote healthy use of free time among middle school adolescents. J ournal of Leisure Research 36: 310-335

Caldwell LL, Darling N, Payne LL and Dowdy B (1999) 'Why are you bored?' An examination of psychological and social control causes of boredom among adolescents. Journal of Leisure Research 31: 103- 121

Caldwell LL and Kivel BD (1998) The leisure context of adolescents who are lesbian, gay male, bisexual and questioning their sexual identities: an exploration study. J ournal of Leisure Research 30: 341- 355

Caldwell LL and Smith EA (1994) Leisure and mental health of high risk adolescents. In: Compton DM \& Iso-Ahola SE (eds), Leisure and Mental Health, Vol. 1. Salt Lake City: Family Development Resources Inc. pp 330- 345

Caldwell LL and Smith EA (1994) Leisure and mental health of high risk adolescents. In Compton DM and Iso-Ahola S (eds), Leisure and Mental Health 1: 330-345

Caldwell LL and Smith EA (1995) Health behaviors of leisure alienated youth. Loisir et Société / Society and Leisure 18: 143- 156

Caldwell LL, Smith EA, Flisher AJ, Wegner L, Vergnani T, Mathews C and Mpofu E (2004) HealthWise South Africa: development of a life skills program for young adults. World Leisure 


\section{Journal 46: 4- 17}

Caldwell LL, Smith EA and Weissinger E (1992) The relationship of leisure activities and perceived health of college students. Loisir et Société / Society and Leisure 15: 545- 556

Costa PT Jr and McCrae RR (1992) Revised NEO Personality Inventory (NEO-PI-R) and NEO Five-Factor Inventory (NEO-FFI) Professional Manual. Odessa, FL: Psychological Assessment Resources

Crandall VC, Crandall VJ and Katkovsky W (1965) A children's social desirability questionnaire. J ournal of Consulting Psychology 29: 27- 36

Crandall R and Slivken K (1980) Leisure attitudes and their measurement. In: Iso-Ahola SE (ed.), Social Psychological Perspectives on Leisure and Recreation. Springfield, IL: CC Thomas. pp 261- 284

Crowne D and Marlow D (1964) The Approval Motive. New York: Wiley

Csikszentmihalyi M (1990) Flow: The Psychology of Optimal Experience. New York:

Harper and Rows Csikszentmihalyi M and Csikszentmihalyi I (1988) Optimal Experience: Psychological Studies of Flow in Consciousness. Cambridge: Cambridge University Press

Csikszentmihalyi M and Larson R (1984) Being Adolescent. New York: Basic Books

Deci EL and Ryan RM (1985) Intrinsic Motivation and Self-Determination in Human Behavior. New York: Plenum Press

Farmer R and Sundberg ND (1986) Boredom proneness: the development and correlates of a new scale. J ournal of Personality Assessment 50: 4- 17

Farnworth L (1998) Doing, being, and boredom. J ournal of Occupational Science 5: 140- 146

Fleming JS and Courtney BE (1984) The dimensionality of self-esteem II hierarchical facet model for revised measurement scales. J ournal of Personality and Social Psychology 46: 404421

Flisher AJ, Mathews C, Mukoma W and Lombard CJ (2006) Secular trends in risk behaviour of Cape Town grade 8 students. South African Medical J ournal 96: 982-987

Gladue BA (1991) Qualitative and quantitative sex differences in self-reported aggressive behaviour characteristics. Psychological Reports 68: 675- 684

Gordon WR and Caltabiano ML (1996) Urban-rural differences in adolescent self-esteem, leisure boredom, and sensation-seeking as predictors of leisure-time usage and satisfaction. Adolescence 31: 883- 901

Harter S (1981) A new self-report scale of intrinsic versus extrinsic orientation in the classroom: Motivational and informational components. Developmental Psychology 17: 300- 312

Hirschi T (1969) Causes of Delinquency. Berkeley: University of California Press 
Iso-Ahola SE and Crowley ED (1991) Adolescent substance abuse and leisure boredom. J ournal of Leisure Research 23: 260-271

Iso-Ahola SE and Weissinger E (1987) Leisure and boredom. Journal of Social and Clinical Psychology 5: 356- 364

Iso-Ahola SE and Weissinger E (1990) Perceptions of boredom in leisure: conceptualisation, reliability and validity of the Leisure Boredom Scale. J ournal of Leisure Research 22: 1- 17

Jessor R and Jessor SL (1977) Problem Behaviour and Psychosocial Development: A Longitudinal Study of Youth. New York: Academic Press

J ones GW (1992) Rural girls and cars: The phenomena of 'blockies'. Rural Society 2: 4- 7

Kaufman CE, Clark S, Manzini N and May J (2002) How community structures of time and opportunity shape adolescent sexual behaviour in South Africa. Policy Research Division, 159. The Population Council. Available at http:// www.popcouncil.org/ publications/wp/ prd/ 159.html [Accessed 15 April 2006]

Klapp O (1986) Overload and Boredom: Essays on the Quality of Life in the Information Society. Connecticut: Greenwood Press

Kolbe LJ, Kahn L and Collins JL (1993) Overview of the youth risk behaviour surveillance system. Public Health Reports 108: 2- 10

Larson RW and Richards MH (1991) Boredom in the middle school years: blaming schools versus blaming students. American J ournal of Education 99: 418- 443

Lerner RM, Freund AM, De Stefanis I and Habermas T (2001) Understanding developmental regulation in adolescence: The use of the selection, optimisation, and compensation model. Human Development 44: 29-50

Mannell RC (1984) Personality in leisure theory: The self-as-entertainment construct. Loisir et Société / Society and Leisure 7: 229-242

Møller V (1991) Lost generation found: black youth at leisure. Indicator South Africa Issue Focus. University of Natal: Centre for Social and Development Studies. pp 1-63

Newberry AL and Duncan RD (2001) Roles of boredom and life goals in juvenile delinquency. J ournal of Applied Social Psychology 31: 527- 541

Oppenheim J (1984) Perceived social competence: boredom and the capacity for selfentertainment. Unpublished Master's thesis, University of Maryland, College Park, MD, USA

Oyserman D and Markus HR (1990) Possible selves and delinquency. Journal of Personality and Social Psychology 59: 112- 125

Patterson GR and Stouthamer-Loeber M (1984) The correlation of family management practices and delinquency. Child Development 55: 1299- 1307 
Patterson IR and Pegg S (1999) 'Nothing to do.' The relationship between leisure boredom and alcohol and drug addiction: is there a link to youth suicide in rural Australia? Youth Studies Australia 18: 24- 29

Patterson I, Pegg S and Dobson-Patterson R (2000) Exploring the links between leisure boredom and alcohol use among youth in rural and urban areas of Australia. Journal of Park and Recreation Administration 18: 53- 75

Pierce RC (1980) Dimensions of leisure I: Satisfactions. J ournal of Leisure Research 12: 5- 19

Porter C, Markus H and Nurius PS (1984) Conceptions of Possibility Among People in Crisis Unpublished manuscript, University of Michigan, USA

Ragheb MG, Merydith SP and Burlingame J (1995) Free Time Boredom. Ravensdale, WA: Idyll Arbor

Reddy SP, Panday S, Swart D, Jinabhai CC, Amosun SL, James S, Monyeki KD, Stevens G, Morojele N, Kambaran NS, Omardien RG and Van den Borne HW (2003) The South African National Youth Risk Behaviour Survey 2002. Cape Town: Medical Research Council

Rosenberg M (1965) Society and Adolescent Self-image. Princeton: Princeton University Press

Ross LE (1995) School environment, self-esteem, and delinquency. J ournal of Criminal J ustice 23: 555-567 Ryan RM and Deci EL (2000) Self-determination theory and the facilitation of intrinsic motivation, socialndevelopment, and well-being. American Psychologist 55: 68- 78

Sharp EH, Caldwell LL, Graham JW and Ridenour T (2006) Individual motivation and parental influence on adolescents' experiences of interest in free time: a longitudinal examination. J ournal of Youth and Adolescence 35: 359- 372

Shaw SM, Caldwell LL and Kleiber DA (1996) Boredom, stress and social control in the daily activities of adolescents. J ournal of Leisure Research 28: 274- 293

Shisana O, Rehle T, Simbayi LC, Parker W, Zuma K, Bhana A, Connolly C, J ooste S, Pillay V et al. (2005) South African National HIV Prevalence, HIV Incidence, Behaviour and Communication Survey, 2005. Cape Town: HSRC Press

Watson D, Clark LA and Tellegen A (1998) Development and validation of brief measures of positive and negative affect: the PANAS scales. J ournal of Personality and Social Psychology 54: 1063- 1070

Wegner L, Flisher AJ, Muller M and Lombard C (2006) Leisure boredom and substance use among high school students in South Africa. J ournal of Leisure Research 38: 249- 266

Weissinger E (1985) The development and validation of an intrinsic leisure motivation scale. Unpublished PhD thesis, University of Maryland, College Park, USA

Weissinger E (1986) Development of a scale to measure individual differences in orientation towards intrinsic motivation. Paper presented at the SPRE Leisure Research Symposium, Anaheim, CA, USA, October 19896 
Weissinger E, Caldwell LL and Bandolas DL (1992) Relation between intrinsic motivation and boredom in leisure time. Leisure Sciences 14: 317- 325

Weissinger E, Caldwell LL and Mobily KE (1987) Use of recreation majors as research subjects: differences between majors and non-majors on leisure-related variables. Paper presented at the Leisure Research Symposium, New Orleans, USA (October 1987).

Widmer MA, Ellis GD and Munson WW (2003) Development of the Aristotelian Ethical Behavior in Leisure Scale short form. Therapeutic Recreation J ournal 37: 256- 274

Widmer MA, Ellis GD and Trunnell EP (1996) Measurement of ethical behavior in leisure among high-and low-risk adolescents. Adolescence 31: 398- 408

Yang $\mathrm{H}$ and Yoh $\mathrm{T}$ (2005) The relationship between free-time boredom and aggressive behavioral tendencies among college students with disabilities. American J ournal of Recreation Therapy 4: 11- 16

Zuckerman M (1978) The search for high sensation. Psychology Today 11: 38-41

Zuckerman M (1979) Sensation-Seeking: Beyond the Optimal Level of Arousal. Hillsdale, NJ : Lawrence Erlbaum

Zuckerman M (1990) The psychophysiology of sensation-seeking. J ournal of Personality 58: 313345 Zuckerman M (1991) Sensation-seeking: the balance between risk and reward. In: Lipsitt L and Mitnick L (eds), Self-regulatory Behavior and Risk-taking: Causes and Consequences. New J ersey: Ablex Publishing Corp. pp 143- 152

Zuckerman M, Kolin EA, Price L and Zoob I (1964) Development of a sensation-seeking scale. J ournal of Counselling Psychology 28: 477-482 
Appendix 1: Description of study samples, measurements and variables

\begin{tabular}{|c|c|c|c|}
\hline $\begin{array}{l}\text { Authors (year) and } \\
\text { study location }\end{array}$ & Sample & Measurements & Variables \\
\hline \multicolumn{4}{|l|}{ Cross-sectional studies } \\
\hline $\begin{array}{l}\text { Barnett (2005) } \\
\text { Midwest USA }\end{array}$ & $\begin{array}{l}\text { Undergraduate students } \\
n=657 \\
\text { Mean age } 20.8 \text { years } \\
\text { Age range } 18-30 \text { years } \\
48 \% \text { males } \\
39 \% \text { European-American } \\
33 \% \text { African -American } \\
17 \% \text { Asian-American } \\
11 \% \text { Hispanic-American }\end{array}$ & $\begin{array}{l}\text { Leisure Experience Battery (Caldwell, } \\
\text { Smith and Weissinger 1992) measures } \\
\text { dimensions of leisure experience: } \\
\text { Boredom: } \alpha=0.69 \\
\text { Challenge: } \alpha=0.70 \\
\text { Awareness: } \alpha=0.55 \\
\text { Anxiety: } \alpha=0.63\end{array}$ & Not applicable. \\
\hline $\begin{array}{l}\text { Barnett and Klitzing (2006) } \\
\text { Midwestern USA (rural) }\end{array}$ & $\begin{array}{l}\text { Undergraduate students } \\
n=999 \\
\text { Mean age } 20.8 \text { years } \\
\text { Age range } 18-30 \text { years } \\
57 \% \text { males } \\
53 \% \text { European-American } \\
28 \% \text { African-American } \\
10 \% \text { Asian-American } \\
9 \% \text { Hispanic-American }\end{array}$ & $\begin{array}{l}\text { Leisure Experience Battery for Young } \\
\text { Adults (Barnett 2005) (boredom, } \\
\text { awareness, challenge and anxiety) } \\
\alpha=0.61 \text { to } 0.89 \\
\text { Revised NEO personality inventory } \\
\text { (Costa and McCrae 1992) (extraversion, } \\
\text { agreeableness, conscientiousness, } \\
\text { neuroticism and openness to experience), } \\
\text { reliable and valid. } \\
\text { Self-as-Entertainment (Mannell 1984) } \\
\text { (self, mind-play and environment), } \\
\text { reliable and valid. } \\
\text { Positive and Negative Affect Scales } \\
\text { Watson, Clark and Tellegen } 1998 \text { ), } \\
\text { internal consistency and valid. } \\
\text { Work Preference Inventory (Amabile et al. } \\
\text { 1994) to measure motivation. } \alpha=0.76-0.82 \\
\text { Demographic information. }\end{array}$ & $\begin{array}{l}\text { Boredom in free } \\
\text { time. }\end{array}$ \\
\hline Caldwell and Kivel (1998) & $\begin{array}{l}\text { Grades } 9-12 \\
n=2756\end{array}$ & $\begin{array}{l}\text { Sexual attraction used as surrogate for } \\
\text { sexual identity. }\end{array}$ & $\begin{array}{l}\text { Binge drinking; } \\
\text { suicide attempts; }\end{array}$ \\
\hline County in south-eastern USA & $\begin{array}{l}n=111(4 \%) \text { identified as gay or } \\
\text { questioning sexual identity } \\
46 \% \text { males } \\
14 \% \text { minority groups }\end{array}$ & $\begin{array}{l}\text { Leisure experience (free time as context } \\
\text { for rebellion), leisure identity, boredom } \\
\text { in free time using index from Leisure } \\
\text { Experience Battery for Adolescents } \\
\text { (Caldwell, Smith and Weissinger 1992), } \\
\text { parental control over leisure, loneliness), } \\
\alpha=0.66-0.74 \text {. } \\
\text { Leisure behaviour (leisure participation, } \\
\text { time spent in leisure), } \alpha=\text { '... low but } \\
\text { acceptable to continue exploratory } \\
\text { analysis' (Caldwell and Kivel 1998: } 344 \text { ). } \\
\text { Health behaviour (binge drinking, suicide } \\
\text { attempts, degree of strain, stress or } \\
\text { pressure, feelings of sadness or } \\
\text { depression), standardised items takes } \\
\text { from Youth Risk Behavior Survey (Kolbe, } \\
\text { - Kahn and Collins } 1993 \text { ). } \\
\text { Item on fear of attending school due to } \\
\text { being threatened by other students. }\end{array}$ & $\begin{array}{l}\text { degree of } \\
\text { strain, stress } \\
\text { or pressure; } \\
\text { feelings of } \\
\text { sadness or } \\
\text { depression. }\end{array}$ \\
\hline
\end{tabular}




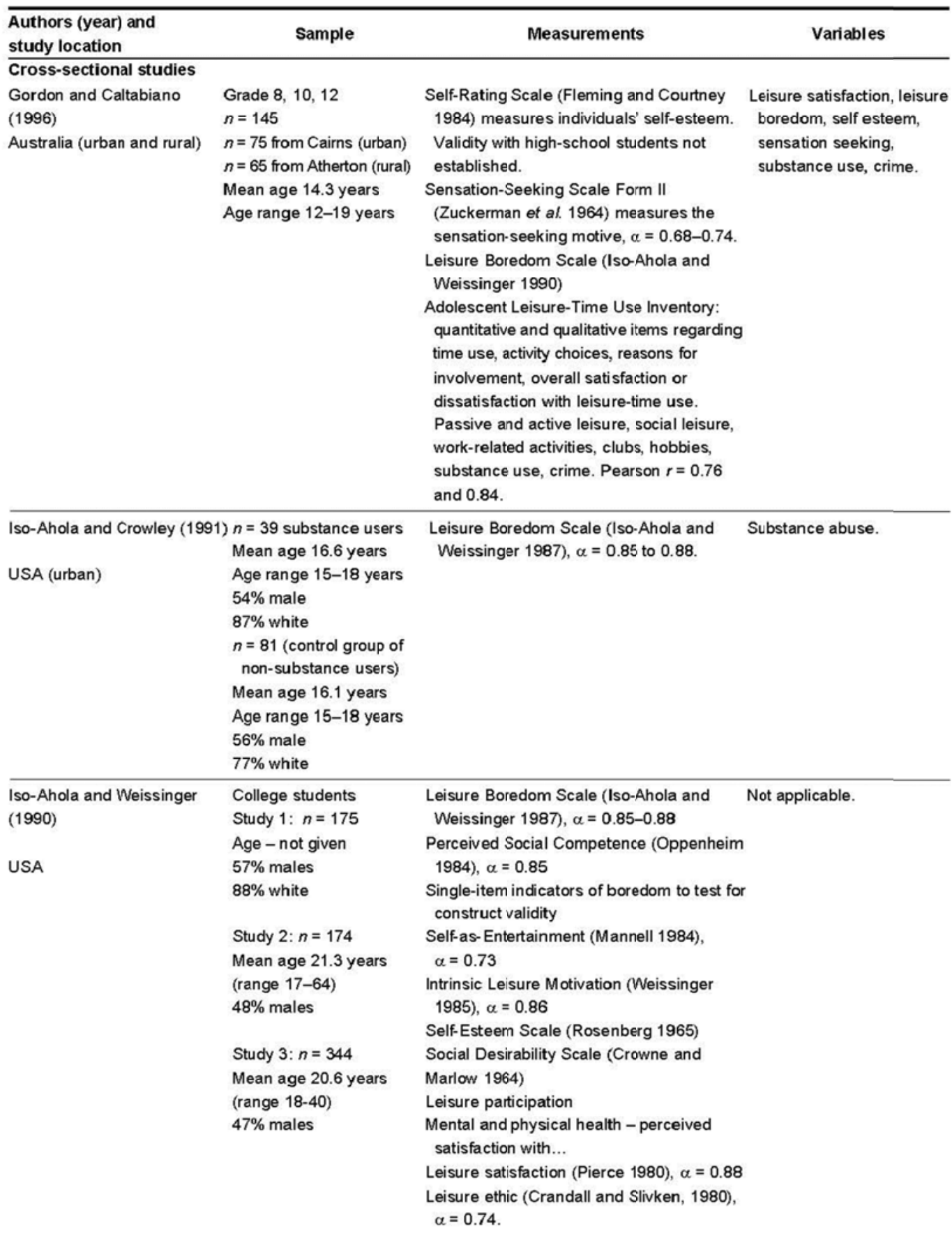




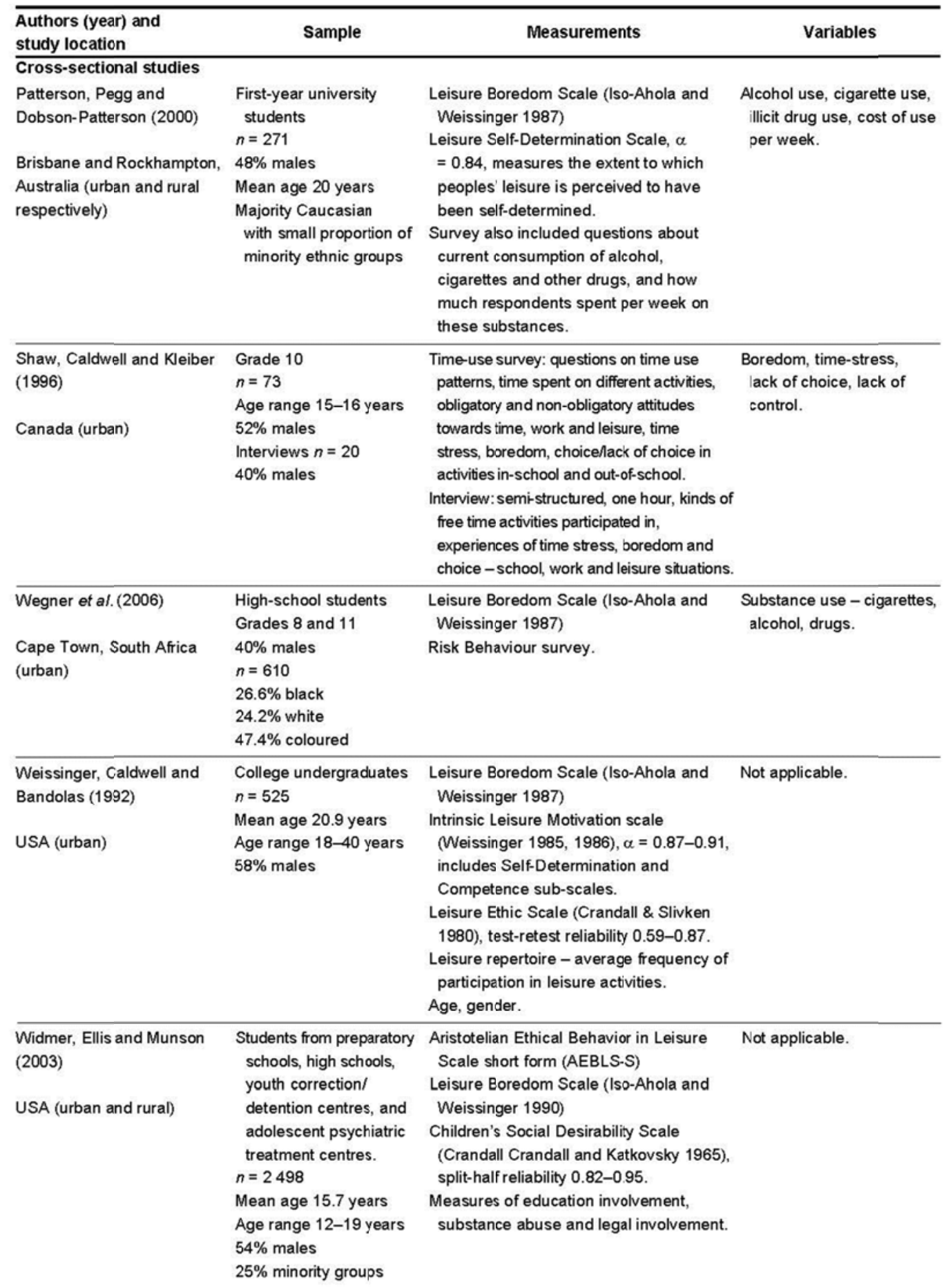




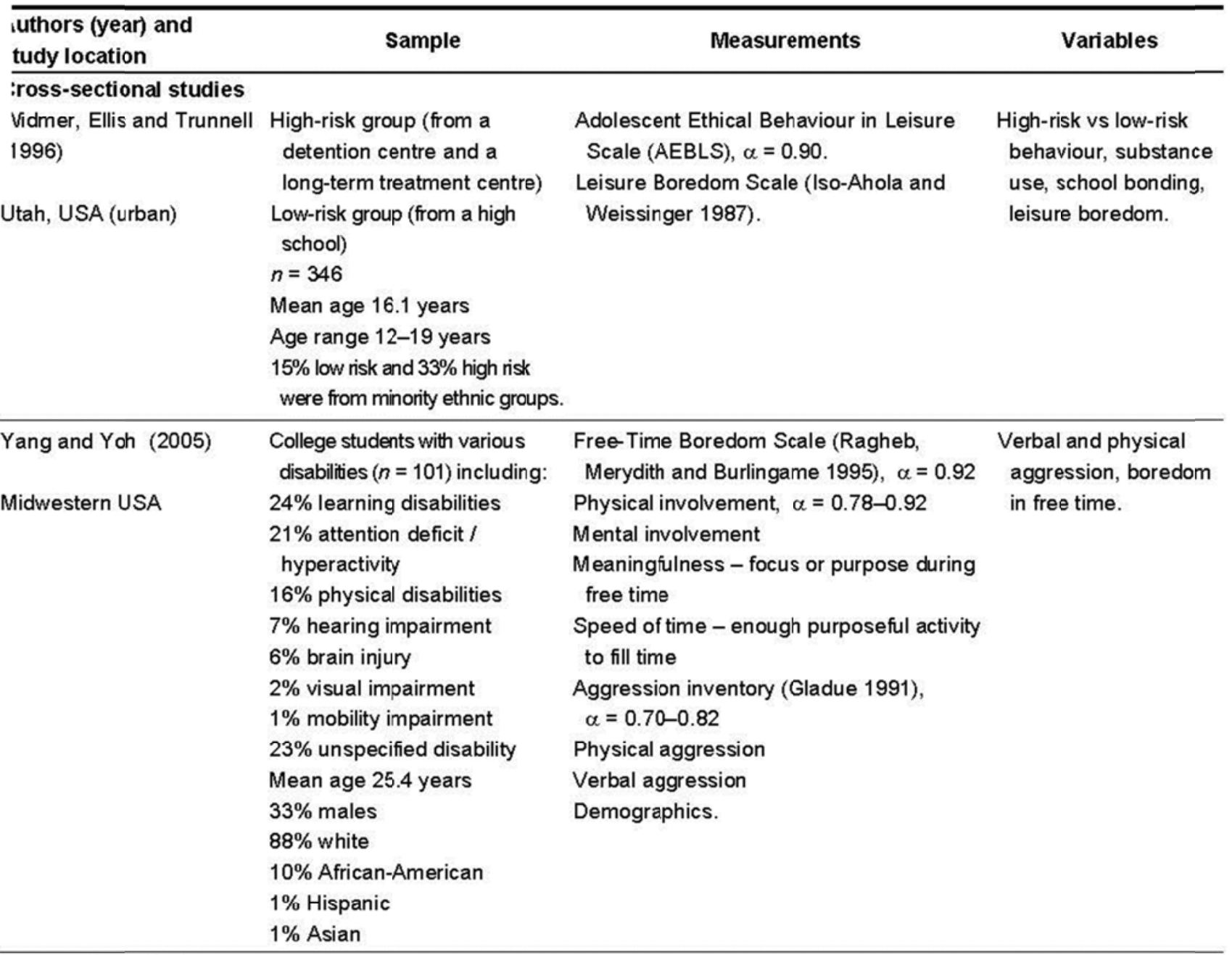

\section{Longitudinal Studies}

Caldwell, Baldwin, Walls and Smith (2004)

Pennsylvania, USA (rural)
Grade 7 students

$n=634$

$49 \%$ male

95\% European-American
Free Time Motivation Scale for Adolescents Distal outcome (Baldwin and Caldwell 2003), $\alpha=0.68-0.78$, substance use. measures amotivation, extrinsic, introjected, identified and intrinsic motivation.

Affective response to leisure, $\alpha=0.75$, degree of boredom and degree to which free time contributes to well-being.

Leisure skills, $\alpha=0.64-0.84$, - initiative, peer influence, planning and decision-making skills, ability to restructure boring situation.

Awareness of, and participation in, leisure activities in communities, $\alpha=0.50-0.72$.

\begin{tabular}{ll}
\hline Caldwell et al. (1999) & Grade 8 students \\
& $n=82$ \\
Pennsylvania, USA (urban) & Mean age 13.2 years \\
& $49 \%$ male \\
& $92 \%$ white
\end{tabular}
free time and problem behaviours (for example
Boredom.

about parents, firends, leisure, school achievement, intrinsic motivation, boredom in vandalism, substance use, etc.)

Follow-up questionnaire at home and interview - parental monitoring, information disclosure to parents, conflict over rules, adolescent autonomy, selfesteem and dating.

Activity diary - assessed daily free time behaviours and experiences. 
Appendix 1: (cont.)

\begin{tabular}{|c|c|c|c|}
\hline $\begin{array}{l}\text { Authors (year) and } \\
\text { study location }\end{array}$ & Sample & Measurements & Variables \\
\hline \multicolumn{4}{|l|}{ Longitudinal Studies } \\
\hline & & $\begin{array}{l}\text { Situation Level variables - reason for } \\
\text { participation in activity, and specific activity. } \\
\text { Individual Difference Level variables - Parental } \\
\text { monitoring (Patterson and Stouthamer-Loeber } \\
\text { 1984), } \alpha=0.80 \text {; and Intrinsic motivation (Harter } \\
1981 \text { ), } \alpha=0.86 \text {. }\end{array}$ & \\
\hline Caldwell et al. (1999) & $\begin{array}{l}\text { Grade } 8 \text { students } \\
n=82\end{array}$ & $\begin{array}{l}\text { In-school questionnaire included questions } \\
\text { about parents, friends, leisure, school }\end{array}$ & Boredom. \\
\hline Pennsylvania, USA (urban) & $\begin{array}{l}\text { Mean age } 13.2 \text { years } \\
49 \% \text { male } \\
92 \% \text { white }\end{array}$ & $\begin{array}{l}\text { achievement, intrinsic motivation, boredom } \\
\text { in free time and problem behaviours (for } \\
\text { example vandalism, substance use, etc.) } \\
\text { Follow-up questionnaire at home and } \\
\text { interview - parental monitoring, information } \\
\text { disclosure to parents, conflict over rules, } \\
\text { adolescent autonomy, self-esteem and } \\
\text { dating. } \\
\text { Activity diary - assessed daily free time } \\
\text { behaviours and experiences. } \\
\text { Situation Level variables - reason for } \\
\text { participation in activity, and specific activity. } \\
\text { Individual Difference Level variables } \\
\text { - Parental monitoring (Patterson and } \\
\text { Stouthamer-Loeber 1984), } \alpha=0.80 \text {; and } \\
\text { Intrinsic motivation (Harter } 1981 \text { ), } \alpha=0.86 \text {. }\end{array}$ & \\
\hline
\end{tabular}




\begin{tabular}{|c|c|c|}
\hline Authors & $\begin{array}{c}\text { Hypothesis I } \\
\text { theoretical framework }\end{array}$ & Main findings \\
\hline $\begin{array}{l}\text { Barnett } \\
\text { and Klitzing } \\
(2006)\end{array}$ & $\begin{array}{l}\text { The study examines the extent to } \\
\text { which individuals are predisposed } \\
\text { to experience boredom regardless } \\
\text { of environmental features. } \\
\text { Individuals' experiences of boredom } \\
\text { in free time are examined, as well } \\
\text { as relationships with personality, } \\
\text { affect, motivation and demographics. }\end{array}$ & $\begin{array}{l}\text { Free Time Boredom (FTB) scale possessed satisfactory reliability for all } \\
\text { student groups (range } 0.61-0.89 \text { ) indicating that the FTB scale could be used } \\
\text { to explore relationships with personality, motivation, and affect. } \\
\text { Most significant predictor of differences in propensity to experience boredom } \\
\text { was the self sub-scale of Self-As-Entertainment - individuals who were poor at } \\
\text { entertaining themselves were most likely to report being bored with unfilled free } \\
\text { time. The mind-play Self-As-Entertainment sub-scale was also predictive- } \\
\text { individuals who turned inward towards fantasy and imagination were most likely } \\
\text { to be bored in their free time. } \\
\text { Two personality traits - extraversion and openness to experiences - also } \\
\text { predicted boredom, in that individuals who were introverted and preferred } \\
\text { novelty and variety in their free-time activities were most likely to feel bored } \\
\text { with unfilled free time. Students who were generally negative in affect also } \\
\text { tended to be more bored. Intrinsic motivation to seek enjoyment was strongly } \\
\text { and inversely related to the propensity to experience boredom in free time. } \\
\text { Therefore, study provided evidence that internal characteristics significantly } \\
\text { predicted free-time boredom. In addition, race and ethnicity, and gender } \\
\text { were significant predictors of boredom. }\end{array}$ \\
\hline
\end{tabular}

\section{Caldwell et When adolescents feel controlled,}

af. (1999) they experience boredom. When adolescents feel autonomous and self-determined, they are less bored. Situational level: the 'want to' situation would produce the lowest levels of boredom.

Individual difference level: high levels of perceived parental monitoring would be predictive of higher levels of leisure boredom. Low levels of intrinsic motivation would predict higher levels of leisure boredom.

\section{Predicting boredom: $23 \%$ of variance in adolescents' reported boredom can} be explained by individual differences, while the remaining $77 \%$ is attributed to situational differences plus error.

At the individual difference level, adolescents with lower intrinsic motivation and lower levels of perceived parental monitoring were more likely to be bored $(p<0.05)$. Gender did not predict individual differences in boredom. Situational level: adolescents participating in an activity because they 'wanted to' were less bored than when they participated because they 'had to' $(p=0.000)$. 'Having no choice' or 'having nothing else to do' were predictive of boredom. Influence of context on reason and boredom - the reason adolescents participate in leisure activities varies by activity type. About $41 \%$ of the time adolescents had 'nothing else to do'.

The effect of reason on boredom by activity - when the reason adolescents participate in an activity is because they 'want to', they experience the lowest level of boredom.

\begin{tabular}{ll}
\hline Caldwell & Ecological Systems Theory \\
and Kivel & (Bronfenbrenner 1992, 1995) \\
(1998) &
\end{tabular}

Gay youth and those questioning their sexual identity experienced leisure differently and more negatively than their non-gay peers $(p<0.000)$. Gay males were more bored in their leisure time than their non-gay peers. Gay males tended to use free time to rebel $(p<0.062)$ and reported that their parents had too much control over their free time. Gay youth were less likely to report doing things in their free time that were healthy $(p<0.008)$, were less likely to go out for fun in the evening $(p<0.011)$ and were less likely to engage in aerobic activity $(p<0.001)$. Gay youth more likely to engage in binge drinking $(p<0.052)$, feel depressed $(p<0.000)$, under stress $(p<0.017)$, and have attempted suicide $(p<0.022)$.

Students more bored in school than leisure.

Caldwell Youth risk behaviour and Smith Problem Behaviour Theory (1994) (Jessor and Jessor 1977)
Male drinkers indicated a higher level of boredom in leisure $(p<0.019)$. Students who went out for fun five or more times a week were more bored than their peers who went out less than five times a week $(p<0.0173)$. Proposed that the Model of Problem Behaviour (Jessor and Jessor 1977) be expanded and modified to include a leisure context. Thus the model posits a relationship among a psychological system, a perceived environmental system, a community system, a leisure behaviour system, and an outcomesof-behaviour system. 
Appendix 2: Evidence of leisure boredom, and the association with risk behaviour

\begin{tabular}{|c|c|c|}
\hline Authors & $\begin{array}{l}\text { Hypothesis / } \\
\text { theoretical framework }\end{array}$ & Main findings \\
\hline $\begin{array}{l}\text { Barnett } \\
\text { and Klitzing } \\
(2006)\end{array}$ & $\begin{array}{l}\text { The study examines the extent to } \\
\text { which individuals are predisposed } \\
\text { to experience boredom regardless } \\
\text { of environmental features. } \\
\text { Individuals' experiences of boredom } \\
\text { in free time are examined, as well } \\
\text { as relationships with personality, } \\
\text { affect, motivation and demographics. }\end{array}$ & $\begin{array}{l}\text { Free Time Boredom (FTB) scale possessed satisfactory reliability for all } \\
\text { student groups (range } 0.61-0.89 \text { ) indicating that the FTB scale could be used } \\
\text { to explore relationships with personality, motivation, and affect. } \\
\text { Most significant predictor of differences in propensity to experience boredom } \\
\text { was the self sub-scale of Self-As-Entertainment - individuals who were poor at } \\
\text { entertaining themselves were most likely to report being bored with unfilled free } \\
\text { time. The mind-play Self-As-Entertainment sub-scale was also predictive - } \\
\text { individuals who turned inward towards fantasy and imagination were most likely } \\
\text { to be bored in their free time. } \\
\text { Two personality traits - extraversion and openness to experiences - also } \\
\text { predicted boredom, in that individuals who were introverted and preferred } \\
\text { novelty and variety in their free-time activities were most likely to feel bored } \\
\text { with unfilled free time. Students who were generally negative in affect also } \\
\text { tended to be more bored. Intrinsic motivation to seek enjoyment was strongly } \\
\text { and inversely related to the propensity to experience boredom in free time. } \\
\text { Therefore, study provided evidence that internal characteristics significantly } \\
\text { predicted free-time boredom. In addition, race and ethnicity, and gender } \\
\text { were significant predictors of boredom. }\end{array}$ \\
\hline
\end{tabular}

Caldwell et When adolescents feel controlled, al. (1999) they experience boredom. When adolescents feel autonomous and self-determined, they are less bored. Situational level: the 'want to' situation would produce the lowest levels of boredom.

Individual difference level: high levels of perceived parental monitoring would be predictive of higher levels of leisure boredom.

Low levels of intrinsic motivation would predict higher levels of leisure boredom.
Predicting boredom: $23 \%$ of variance in adolescents' reported boredom can be explained by individual differences, while the remaining $77 \%$ is attributed to situational differences plus error.

At the individual difference level, adolescents with lower intrinsic motivation and lower levels of perceived parental monitoring were more likely to be bored $(p<0.05)$. Gender did not predict individual differences in boredom. Situational level: adolescents participating in an activity because they 'wanted to' were less bored than when they participated because they 'had to' $(p=0.000)$. 'Having no choice' or 'having nothing else to do' were predictive of boredom. Influence of context on reason and boredom - the reason adolescents participate in leisure activities varies by activity type. About $41 \%$ of the time adolescents had 'nothing else to do'.

The effect of reason on boredom by activity - when the reason adolescents participate in an activity is because they 'want to', they experience the lowest level of boredom.

\begin{tabular}{ll}
\hline Caldwell & Ecological Systems Theory \\
and Kivel & (Bronfenbrenner 1992, 1995) \\
(1998) &
\end{tabular}

Gay youth and those questioning their sexual identity experienced leisure differently and more negatively than their non-gay peers $(p<0.000)$. Gay males were more bored in their leisure time than their non-gay peers. Gay males tended to use free time to rebel $(p<0.062)$ and reported that their parents had too much control over their free time. Gay youth were less likely to report doing things in their free time that were healthy $(p<0.008)$, were less likely to go out for fun in the evening $(p<0.011)$ and were less likely to engage in aerobic activity $(p<0.001)$. Gay youth more likely to engage in binge drinking $(p<0.052)$, feel depressed $(p<0.000)$, under stress $(p<0.017)$, and have attempted suicide $(p<0.022)$.

Students more bored in school than leisure.

Male drinkers indicated a higher level of boredom in leisure $(p<0.019)$.

Students who went out for fun five or more times a week were more bored than their peers who went out less than five times a week $(p<0.0173)$. Proposed that the Model of Problem Behaviour (Jessor and Jessor 1977) be expanded and modified to include a leisure context. Thus the model posits a relationship among a psychological system, a perceived environmental system, a community system, a leisure behaviour system, and an outcomesof-behaviour system. 


\begin{tabular}{|c|c|c|}
\hline Authors & $\begin{array}{c}\text { Hypothesis / } \\
\text { theoretical framework }\end{array}$ & Main findings \\
\hline $\begin{array}{l}\text { Caldwell } \\
\text { and Smith } \\
(1995)\end{array}$ & $\begin{array}{l}\text { Models of boredom: } \\
\text { Cognitive } \\
\text { Psychological } \\
\text { Social construction }\end{array}$ & $\begin{array}{l}\text { Found a relationship between alienated leisure and high-risk health behaviours } \\
\text { with approx } 9 \% \text { males and } 8 \% \text { females feeling that leisure time was boring, } \\
\text { and approx } 17 \% \text { females and } 19 \% \text { males using leisure time to get back at } \\
\text { parents and society. Both males and females who fell into this alienated } \\
\text { leisure category engaged in higher levels of at-risk health behaviours than } \\
\text { their peers. } \\
\text { Females who were bored engaged less in leisure activities than their peers. } \\
\text { Bored males were less likely to go out in the evenings for fun. Study questions } \\
\text { the positive benefits of leisure for leisure-alienated youth. }\end{array}$ \\
\hline
\end{tabular}

Farnworth Boredom as lack of challenge (Csiks(1998) zentmihalyi \& Csikszentmihalyi 1988) Boredom is a state where person perceives challenge of task to be less than their skills.

Boredom as underarousal (boredom susceptibility, thrill seeking indicate underarousal as basis for boredom) (e,g. Zuckerman 1990, 1991)

Boredom as information overload (Klapp 1986)

Overload of information experienced as noise, the more noise in the environment, the less meaning we can receive.

Gordon and A relationship exists between Caltabiano leisure opportunities and leisure (1996) satisfaction.

The total leisure participation hours and types of leisure activities adolescents choose will be a function of interactive effects between self-esteem and sensationseeking, self-esteem and leisure boredom, and sensation-seeking and leisure boredom.

A positive relationship exists between self-esteem, leisure control and leisure satisfaction.
$57 \%$ of wakeful hours of young offenders was spent in leisure occupations, predominantly passive leisure such as listening to music or watching TV. Participants reported feeling bored $42 \%$ of the times they were beeped. $62 \%$ of their reported time was spent in occupations that they experienced as under-challenging in relationship to their perceived skills. Boredom was experienced significantly more in passive than active leisure occupations.
Mean number of hours spent per week on leisure was 54.7 (SD 26.9).

Reported participation rates were highest for passive leisure and lowest for active leisure.

Urban adolescents spent highest number of hours in social leisure and rural adolescents in passive leisure.

Rural adolescents scored higher on LBS ( $M=36$, range 16-59) than urban adolescents ( $M=34$, range 14-59).

Significant two-way interaction effects between sensation-seeking, leisure boredom, and self esteem were found for substance use for each location. Urban adolescents who engaged most heavily in substance use had low self-esteem and high leisure boredom $(p<0.05)$.

Urban adolescents who scored high on both sensation-seeking and leisure boredom, engaged most heavily in substance use $(p<0.05)$.

Among rural adolescents, self-esteem interacted with leisure boredom, indicating that the heaviest substance users had low self-esteem and scored low on leisure boredom $(p<.05)$.

Thus for rural adolescents, low self-esteem had a greater effect than sensation seeking, whereas high sensation seeking had more of an effect on urban adolescents' substance use than did self-esteem.

Iso-Ahola There is a relationship between and Crowley substance use, leisure boredom (1991) and leisure participation. Adolescent substance users are more likely to experience leisure boredom than non-substance users.
Substance abusers were significantly more bored with leisure than non-substance users $(p<0.001)$.

Substance abusers' frequency of participation in leisure was significantly higher than non-substance users $(p<0.032)$.

Explanation: adolescent substance users tended to differ from non-substance users in that they were more likely to be sensation seekers with a low tolerance for repetitious activities (Zuckerman 1978).

Substance users engaged more often in leisure activities but become bored easily especially if the activity did not meet their need for optimal arousal (Csikszentmihalyi 1990). May potentially lead to substance use and other anti-social activities. 


\begin{tabular}{lc}
\hline Authors & $\begin{array}{c}\text { Hypothesis / } \\
\text { theoretical framework }\end{array}$ \\
\hline
\end{tabular}

Kaufman ef al. (2002) The importance of contextual factors on adolescent behaviour in South Africa.

Theories of community effects on adolescents' behaviour.

The extent to which adolescents perceive community opportunities and then take advantage of them will shape their sexual risk-taking behaviour.

\section{Main findings}

$47 \%$ adolescents had sex in last 12 months. Of these, $47 \%$ used condom at last sex. $9 \%$ had 2 or more partners.

Time-use differences for race and gender: African and Indian females spent twice as much time as their male counterparts in unpaid work.

African (12\%) and Indian ( $9 \%$ ) boys spent the most time hanging out (defined as doing nothing, hanging out at the mall or street corner, going to bars or parties - generally unsupervised and unstructured activities).

African and Indian males reported the highest proportion of time in organised activities (6\%) (sports, music, church groups, other programs and clubs). In contrast, girls reported little hanging out time ( $7 \%$ or less), and relatively low levels of participation in organised activities (4\% or less).

Association of time-use and risky behaviour: Number of hours spent hanging out is positively associated with having had sex in last year, (significant in African boys $p=0.000$, African girls $p=0.000$ and Indian boys $p=0.031$ ).

Number of hours spent hanging out is negatively associated with condom use, but not significant for any group. Girls participating in sports were significantly less likely to report having sex in past year $(p<0.024)$. Whereas boys who participated in sports were significantly more likely not to use condoms $(p<0.005)$. May be because participation in sport increases opportunities for sex and enhances perception that 'real men' don't use condoms. Results suggest that opportunities - or the lack of them - are likely to influence adolescents' sexual behaviour. Programmes/policies will influence behaviour only to the extent that they make sense in the context of the person's life.

Larson and Richards (1991)
Do students define boredom in association with understimulation, forced effort or resistance?

Do they experience boredom primarily in school, or also outside of school?

Is boredom uniform across school (resistance) or does it vary by type of school activity (reflecting more immediate conditions)?

Does boredom increase as children move into the more oppositional stage of adolescence?

Does the frequency of boredom vary by individual, and if so, is it related to ability level, psychological dispositions such as depression, or indicators of opposition to school and authority?
Boredom co-occurred with tiredness and drowsiness $(p<0.001)$ (understimulation) indicating a state of lower arousal, with frustration $(p<0.01)$ (forced-effort), and anger $(p<0.001)$ (resistance).

Boredom was not confined to school work but occurred across all domains of adolescents' lives.

The same youths who reported higher boredom during school work also experienced high rates of boredom outside school. Boredom outside school was most frequently attributed to having nothing to do (understimulation).

Rates of boredom during class are not constant but vary according to task context - boredom highest in academic subjects such as science and lowest in applied subjects such as art and gym. Boredom higher in passive activities such as listening to teacher and lower in social, interactive activities such as discussions. Boredom during non-schoolwork time is higher in seventh and eighth graders but falls to below elementary school levels in the ninth grade (attributed this to entry into senior high school) $(p<0.009)$.

Rates of boredom during school and after school were highly correlated $(r=.68)$ indicating strong contribution of individual differences, and that boredom is not wholly a product of context.

Boredom outside of schoolwork was not related to SES. Free time boredom was significantly correlated with socially disruptive behaviour and marginally correlated with mental health (depression and self-esteem). 


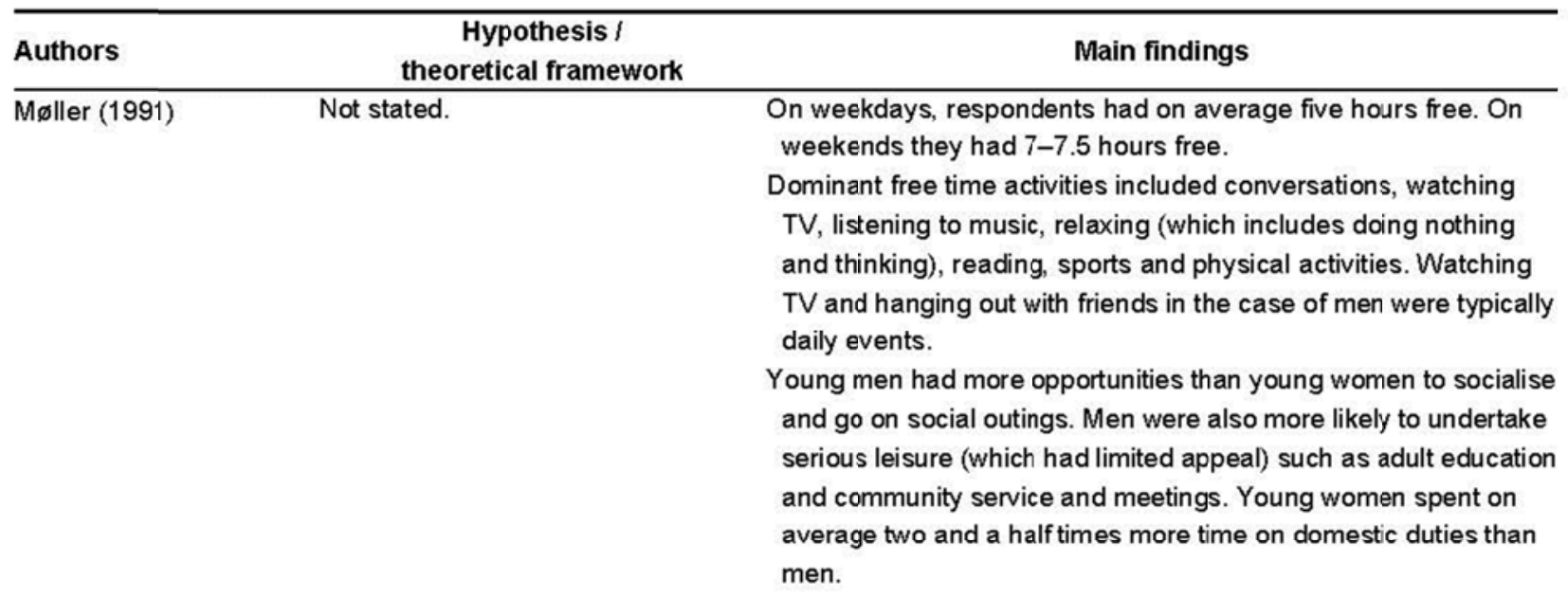

Relative to other young people, the unemployed and housewives had the most free time, yet were most at risk of leisure deprivation as they were unable to utilise this time. Over half of these respondents complained of boredom in their lives. Thus is it the quality of spare time and not the quantity which influences well-being.

Major perceived constraints to leisure were money, lack of facilities and few opportunities to access facilities. Lack of permission from home constrained younger adolescents and women.

Approx. one-third reported that their friends smoked cigarettes and hung around in groups. $30 \%$ reported that their friends drank alcohol and $6 \%$ used dagga. The reported incidence of problem behaviour (substance use and pick-pocketing) was lowest for young women and highest for unemployed youth (significance not stated).

Newberry and Duncan Concept of possible selves (2001)
(Oyserman and Markus 1990): the representation of the self that each person would like to become, could become, and is afraid of becoming.
Significant gender difference in boredom proneness: males reported higher boredom proneness than females $(p=0.001)$. Boredom proneness related to delinquency $(p=0.0001)$. Tendency to experience boredom related to arrestable behaviours $(p=0.0001)$.

Tendency to experience boredom related to number of non-arrestable delinquent behaviours reported $(p=0.0001)$. Adolescents involved in delinquent activities are prone to experience boredom.
Patterson, Pegg and Dobson-Patterson (2000)

\footnotetext{
Leisure as free time is not always positive, No significant difference in LBS scores in urban (mean score and may result in leisure boredom. 32.50 ) vs rural (mean score 33.32).

Boredom is related to detrimental behaviour such as delinquency, Therefore, no significant relationship between geographical area and leisure boredom.

extreme sensation-seeking activity There was a significant interaction between gender and and substance use. geographical area in terms of LBS scores.

Rural females experienced higher LB than rural males, compared to urban males and females, who did not differ experience leisure boredom. Substance users more likely to be sensation-seekers and have lower tolerance for repetitious activities (Zuckerman 1978). Important for adolescents with substance use problems to participate in positive leisure activities. significantly. Therefore, the rural female group experienced highest levels of leisure boredom. This supports findings of Jones (1992) who concluded that for young girls growing up in rural areas of Australia, there was nothing to do in comparison with young boys. In addition, rural communities offered few recreation facilities to cater for the interests of young women, especially those who were not sports-minded.
} 


\begin{tabular}{|c|c|c|}
\hline Authors & $\begin{array}{l}\text { Hypothesis / } \\
\text { theoretical framework }\end{array}$ & Main findings \\
\hline Sharp ef al. (2006) & $\begin{array}{l}\text { Study examined whether } \\
\text { adolescents' motivational styles } \\
\text { (self-regulation and amotivation) } \\
\text { mediated the role of parental } \\
\text { knowledge and control on the } \\
\text { development and sustenance of } \\
\text { interest in free time. } \\
\text { It was expected that experiences of } \\
\text { interest and self-regulation would } \\
\text { decrease, while amotivation would } \\
\text { increase across the midde school years. } \\
\text { Parental knowledge and parental } \\
\text { control of adolescent free time } \\
\text { would decrease across } 7 \text { th, 8th } \\
\text { and 9th grades. } \\
\text { It was expected that adolescents' } \\
\text { motivational styles would mediate } \\
\text { the impact that parental practices } \\
\text { had on adolescent experiences of } \\
\text { interest. }\end{array}$ & $\begin{array}{l}\text { Youth reported higher levels of amotivation in 9th grade compared } \\
\text { to } 7 \text { th and } 8 \text { th grades. } \\
\text { Youth reported lower levels of self-regulated motivation in 9th } \\
\text { grade compared to } 7 \text { th grade. } \\
\text { Youth reported higher levels of interest during free time in 7th and } \\
\text { 8th grades compared to } 9 \text { th grade. } \\
\text { Compared to males, females reported higher levels of parental } \\
\text { knowledge of their free time use. Males reported greater interest } \\
\text { in free time than females. } \\
\text { There were no significant grade level differences in parental } \\
\text { knowledge or parental control. } \\
\text { Parental knowledge had a direct positive impact on adolescent } \\
\text { interest. Parental knowledge was associated with adolescents } \\
\text { having more motivation and being more self-regulated in their } \\
\text { free time. } \\
\text { Parental control had a direct negative impact on adolescents' } \\
\text { interest. Parental control had a significant positive association } \\
\text { with amotivation. } \\
\text { For both males and females, amotivation was significantly } \\
\text { negatively related to experiences of interest, stronger for females. }\end{array}$ \\
\hline $\begin{array}{l}\text { Shaw, Caldwell and } \\
\text { Kleiber } \\
\text { (1996) }\end{array}$ & $\begin{array}{l}\text { Social control theory - adolescent } \\
\text { time use is structured largely by } \\
\text { adults. } \\
\text { Adolescent experiences and } \\
\text { behaviours can be regarded } \\
\text { as a response to, reaction to, or } \\
\text { alienation of adult structures. }\end{array}$ & $\begin{array}{l}\text { Students spent half their waking time in non-obligatory activities. } \\
\text { Females spent more time in obligatory activities than males. Most } \\
\text { common non-obligatory activity was social activities with friends } \\
\text { including hanging out, talking on phone and parties. } \\
\text { Approximately half students reported that they often felt rushed } \\
\text { (time stress) both in and out of school. } \\
\text { Female students experienced greater time stress out of school } \\
\text { than males. } \\
\text { Time stress was related to the demands and expectations of } \\
\text { adult-structured activities. } \\
\text { Tendency for male students to report boredom more often than } \\
\text { female students both in and out of school, although not } \\
\text { statistically significant. } \\
\text { Some of the boredom and stress experienced was related to } \\
\text { adolescent responses to adult structures, including adult } \\
\text { expectations (school, home and recreation), and family free } \\
\text { time activities. } \\
\text { Some adolescents felt a degree of lack of choice in discretionary } \\
\text { activities because of pressure from adults and friends. Thus } \\
\text { evidence that social control mechanisms affect free time and } \\
\text { leisure experiences of adolescents. Study suggests that social } \\
\text { control mechanisms are gendered - females affected more by } \\
\text { social control mechanisms. }\end{array}$ \\
\hline
\end{tabular}

Wegner et al. (2006) Leisure boredom would be related Younger students reported higher leisure boredom than older to substance use, age, gender and race. students $(p<0.055)$.

Female students reported higher leisure boredom than male students $(p<0.003)$.

Black students reported relatively higher leisure boredom than coloured students, with white students reporting relatively lowest leisure boredom $(p<0.000)$.

No significant association between leisure boredom and substance use. However for all three substances, students who scored $41-50$ on LBS were at lowest risk of using substances. This was significant for recent alcohol use $(p=0.003)$. 


\begin{tabular}{|c|c|c|}
\hline Authors & $\begin{array}{c}\text { Hypothesis / } \\
\text { theoretical framework }\end{array}$ & Main findings \\
\hline $\begin{array}{l}\text { Weissinger, Caldwell } \\
\text { and Bandolas (1992) }\end{array}$ & $\begin{array}{l}\text { Higher levels of desire for intrinsic } \\
\text { rewards (self-determination and } \\
\text { competence) would be strong and } \\
\text { negative predictors of boredom in } \\
\text { leisure time. }\end{array}$ & $\begin{array}{l}\text { The self-determination sub-scale of the Leisure Motivation Scale } \\
\text { explained the greatest amount of variance in boredom. The } \\
\text { competence sub-scale explained the next greatest amount of } \\
\text { variance, followed by leisure ethic, and leisure repertoire. Higher } \\
\text { levels of self-determination, competence, leisure ethic, age and } \\
\text { leisure repertoire were associated with lower levels of leisure } \\
\text { boredom. } \\
\text { Gender was not a significant predictor of leisure boredom. }\end{array}$ \\
\hline $\begin{array}{l}\text { Widmer, Ellis } \\
\text { and Munson } \\
(2003)\end{array}$ & $\begin{array}{l}\text { Reducing number of items in an } \\
\text { instrument may have a negative } \\
\text { impact on reliability and validity. } \\
\text { The AEBLS-S should be able to } \\
\text { differentiate between adolescents } \\
\text { who are living an ethical leisure } \\
\text { lifestyle and those who are not. } \\
\text { High scores on the AEBLS-S should } \\
\text { be associated with high educational } \\
\text { performance and aspirations, and } \\
\text { low dispositional boredom. } \\
\text { High scores on the AEBLS-S should } \\
\text { predict low levels of substance use } \\
\text { and low levels of criminal involvement. }\end{array}$ & $\begin{array}{l}\text { Reliability - the alpha reliability estimates of the AEBLS-S were } \\
0.88 \text { and deemed appropriate. } \\
\text { Internal consistency estimates for LBS were } 0.83 \\
\text { Validity - results support criterion-related evidence of validity of } \\
\text { inferences that may be made from AEBLS-S. } \\
\text { Significant, moderate correlation between AEBLS-S and } \\
\text { educational performance }(p<0.0001) \text {. } \\
\text { Weak but significant negative correlation between AEBLS-S and } \\
\text { substance abuse }(p<0.001) \text {. } \\
\text { Significant negative correlation between AEBLS-S and } \\
\text { dispositional leisure boredom ( } p<0.001) \text {. } \\
\text { AEBLS-S scores between risk groups were significantly different. }\end{array}$ \\
\hline $\begin{array}{l}\text { Widmer, Ellis } \\
\text { and Trunnell (1996) }\end{array}$ & $\begin{array}{l}\text { Aristotelian ethical life perspective: } \\
\text { characterised by a curious, inquisitive } \\
\text { approach to life that leads to } \\
\text { learning beyond that needed for } \\
\text { survival, meaningful relationships } \\
\text { and moral behaviour. } \\
\text { Aristotelian ethical leisure behaviour: } \\
\text { intellectual activity, creative activity, } \\
\text { meaningful relationships, moral } \\
\text { behaviour. }\end{array}$ & $\begin{array}{l}\text { Low risk group scored higher on AEBLS than high risk group } \\
(p<0.05) \text {. } \\
\text { Significant positive correlation between AEBLS scores and } \\
\text { school bonding }(p<0.001) \text {. } \\
\text { Significant negative correlation between AEBLS scores and } \\
\text { leisure boredom }(p<0.001) \text {. } \\
\text { Significant negative correlation between AEBLS scores and } \\
\text { substance use }(p<0.001) \text {. }\end{array}$ \\
\hline Yang and Yoh (2005) & $\begin{array}{l}\text { There would be a positive relationship } \\
\text { between aggressive behavioural } \\
\text { tendency and perceived free-time } \\
\text { boredom among college students } \\
\text { with disabilities. }\end{array}$ & $\begin{array}{l}\text { Participants had a relatively low level of free-time boredom and } \\
\text { perceived their free time as being relatively free from boredom. } \\
\text { Respondents wanted their free time activities to last longer and } \\
\text { to feel comfortable with their speed. } \\
\text { There was a positive correlation between aggressive behavioural } \\
\text { tendency and free-time boredom }(p<0.05) \text {. Suggests that } \\
\text { college students with disabilities are more likely to become } \\
\text { aggressive when they feel bored. } \\
\text { There was a significant correlation between aggressive behavioural } \\
\text { tendency and speed of time, in other words, respondents tended } \\
\text { to become more aggressive when they felt like time was } \\
\text { standing still. }\end{array}$ \\
\hline
\end{tabular}


Appendix 3: Measurement of leisure boredom

\begin{tabular}{|c|c|c|}
\hline Authors & Hypothesis / theoretical framework & Main findings \\
\hline Barnett (2005) & $\begin{array}{l}\text { Based on the Leisure Experience } \\
\text { Battery (LEB) for adolescents } \\
\text { (Caldwell et al. 1992), the aim was } \\
\text { to establish the psychometric } \\
\text { properties of the LEB for use with } \\
\text { college students. }\end{array}$ & $\begin{array}{l}\text { Data indicated internal consistency in items and that LEB could be } \\
\text { used with college students (with minor modifications). } \\
\text { Internal consistency (alpha) scores for sub-scales were: } 0.73 \text { for } \\
\text { Boredom, } 0.72 \text { for Challenge, } 0.67 \text { for Awareness, } 0.67 \text { for } \\
\text { Anxiety (alpha increased to } 0.74 \text { when one item was deleted). } \\
\text { Results of principal components analysis on reduced sub-scale } \\
\text { items were similar to those obtained with adolescents (Caldwell } \\
\text { et al. 1992) with few exceptions; one item from each of the } \\
\text { Awareness, Boredom and Anxiety sub-scales was removed to } \\
\text { improve alpha for that sub-scale. } \\
\text { Students who reported being aware of leisure resources were } \\
\text { significantly less bored in their free time than those who were } \\
\text { less aware. Most students who found their free time boring were } \\
\text { more likely to become distressed about not having things to do or } \\
\text { planned in advance. } \\
\text { Individuals who liked to experience a challenge in their leisure } \\
\text { were usually less bored with their free time. }\end{array}$ \\
\hline $\begin{array}{l}\text { Caldwell, Smith \& } \\
\text { Weissinger (1992) }\end{array}$ & $\begin{array}{l}\text { Goal was to produce parsimonious, } \\
\text { yet internally consistent measures } \\
\text { of selected dimensions of the } \\
\text { adolescent leisure experience. } \\
\text { The Leisure Experience Battery for } \\
\text { Adolescents (LEBA) was developed } \\
\text { based on four dimensions of } \\
\text { the leisure experience: Boredom, } \\
\text { Challenge, Awareness, Anxiety. }\end{array}$ & $\begin{array}{l}\text { The LEB scale showed promising reliability for use with } \\
\text { adolescents. Internal consistency (alpha) scores were: } 0.70 \text { for } \\
\text { Boredom, } 0.70 \text { for Challenge, } 0.55 \text { for Awareness, } 0.63 \text { for } \\
\text { Anxiety (grade } 11 \text { ). } \\
\text { Although somewhat low, this may be due to relatively low number } \\
\text { of items in each scale }(4,3,4,3 \text { respectively). } \\
\text { Pattern of factor structure remained almost identical over time } \\
\text { (grades } 10 \text { and } 11 \text { ). Correlations of scales and factors over time } \\
\text { indicated stability of measurement. }\end{array}$ \\
\hline $\begin{array}{l}\text { Iso-Ahola \& } \\
\text { Weissinger } \\
\text { (1990) }\end{array}$ & $\begin{array}{l}\text { Leisure boredom expected to } \\
\text { be negatively related to social } \\
\text { competence, self-esteem, self-as- } \\
\text { entertainment, social desirability, } \\
\text { intrinsic leisure motivation, social } \\
\text { desirability, leisure satisfaction, } \\
\text { leisure ethic, frequency of } \\
\text { participation in leisure activities, } \\
\text { perceived satisfaction with mental } \\
\text { and physical health. }\end{array}$ & $\begin{array}{l}\text { Results of the three separate studies reported in this article } \\
\text { provided support for the reliability and validity of the LBS with } \\
\text { alphas }=0.85,0.88 \text {, and } 0.86 \text { respectively. } \\
\text { The data demonstrated that the scale was internally consistent. } \\
\text { All constructs were significantly correlated in the predicted manner } \\
\text { further supporting validity and usability of the LBS. }\end{array}$ \\
\hline
\end{tabular}


Appendix 4: Interventions addressing leisure boredom

\begin{tabular}{|c|c|c|}
\hline Authors & Hypothesis / theoretical framework & Main findings \\
\hline $\begin{array}{l}\text { Caldwell, Baldwin, Walls } \\
\text { \& Smith (2004) }\end{array}$ & $\begin{array}{l}\text { TimeWise is a school-based curriculum } \\
\text { which aims to increase positive use of free } \\
\text { time and prevent initiation of risk behaviour. } \\
\text { Theoretical basis: } \\
\text { - Selective optimisation with compensation } \\
\text { (SOC) theory (Lerner, Freund, De Stefanis } \\
\text { \& Habermas } 2001 \text { ) - goal selection, } \\
\text { goal pursuit, goal maintenance, and goal } \\
\text { reformulation gives framework for activity } \\
\text { engagement. } \\
\text { - Self-determination theory (SDT) (Deci \& } \\
\text { Ryan 1985, Ryan \& Deci } 2000 \text { ) - provides } \\
\text { framework for assessing underlying } \\
\text { motivational states associated with variation } \\
\text { in activity engagement. }\end{array}$ & $\begin{array}{l}\text { External motivation decreased over time }(p=0.009) \text {. } \\
\text { Males had higher levels of external motivation than } \\
\text { females ( } p=0.002) \text {. } \\
\text { Intervention had desired effect on motivation by } \\
\text { increasing students' internalised behaviour (identified } \\
p=0.000 \text {, introjected motivation } p=0.045) \text { and } \\
\text { decreasing levels of amotivation }(p=0.010) \text {. } \\
\text { Intervention students reported increased interest and } \\
\text { participation in new activities ( } p=0.011 \text { ) and lower } \\
\text { levels of boredom ( } p=0.010) \text {, higher initiative ( } p= \\
0.038 \text { ) and ability to restructure boring situations into } \\
\text { more interesting ones ( } p=0.005 \text { ). } \\
\text { Suggested that youth who received the intervention } \\
\text { may be more protected against initiation of risk } \\
\text { behaviours, and became more engaged with their } \\
\text { environments. Intervention showed that youth can } \\
\text { learn to become more responsible for their leisure by } \\
\text { thinking about their levels of motivation and finding out } \\
\text { about interesting, fulfilling leisure activities. }\end{array}$ \\
\hline $\begin{array}{l}\text { Caldwell, Smith, Flisher, } \\
\text { Mathews, Wegner, } \\
\text { Vergnani \& Mpofu (2004) }\end{array}$ & $\begin{array}{l}\text { HealthWise hypothesised programme } \\
\text { effects included: } \\
\text { - Lower use of substances. } \\
\text { - Delayed onset of sexual intercourse } \\
\text { - Greater use of condoms. } \\
\text { - Higher levels of participation in leisure } \\
\text { activities. } \\
\text { - Less boredom during free time and greater } \\
\text { ability to develop interests. } \\
\text { - Greater ability to plan and make decisions } \\
\text { about free-time activities, and greater } \\
\text { initiative. }\end{array}$ & $\begin{array}{l}\text { Curriculum was well-received, and perceived to be } \\
\text { useful. However, process evaluation data enabled } \\
\text { some important revisions to be made. One major } \\
\text { revision was the recruitment of two recreation } \\
\text { specialists to work with students in the classroom and } \\
\text { the community, to afacilitate leisure participation. } \\
\text { Outcomes: not yet available. }\end{array}$ \\
\hline
\end{tabular}

